\title{
Working
}

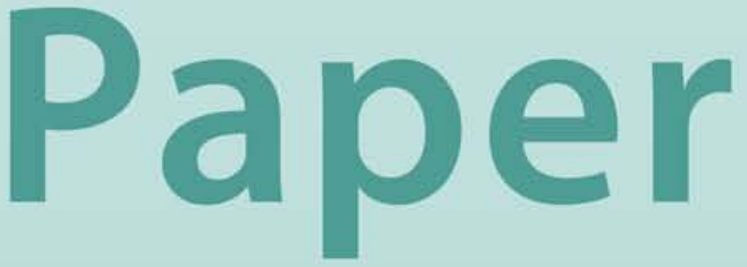




\title{
Procyclical Fiscal Policy: Shocks, Rules, and Institutions-A View From MARS
}

\author{
Paolo Manasse
}


(C) 2006 International Monetary Fund

WP/06/27

\title{
IMF Working Paper
}

Fiscal Affairs Department

\section{Procyclical Fiscal Policy: Shocks, Rules, and Institutions—A View From MARS}

\author{
Prepared by Paolo Manasse ${ }^{1}$ \\ Authorized for distribution by Manmohan S. Kumar
}

January 2006

\begin{abstract}

\section{This Working Paper should not be reported as representing the views of the IMF.} The views expressed in this Working Paper are those of the author(s) and do not necessarily represent those of the IMF or IMF policy. Working Papers describe research in progress by the author(s) and are published to elicit comments and to further debate.
\end{abstract}

This paper assesses the roles of shocks, rules, and institutions as possible sources of procyclicality in fiscal policy. By employing parametric and nonparametric techniques, I reach the following four main conclusions. First, policymakers' reactions to the business cycle is different depending on the state of the economy — fiscal policy is "acyclical" during economic bad times, while it is largely procyclical during good times. Second, fiscal rules and fiscal responsibility laws tend to reduce the deficit bias on average, and seem to enhance, rather than to weaken, countercyclical policy. However, the evidence also suggests that fiscal frameworks do not exert independent effects when the quality of institutions is accounted for. Third, strong institutions are associated to a lower deficit bias, but their effect on procyclicality is different in good and bad times, and it is subject to decreasing returns. Fourth, unlike developed countries, fiscal policy in developing countries is procyclical even during (moderate) recessions; in "good times," however, fiscal policy is actually more procyclical in developed economies.

JEL Classification Numbers: E62, E63, H62, C45, D78

Keywords: Fiscal policy, fiscal rules, procyclicality, institutions

Author(s) E-Mail Address: pmanasse@imf.org, manasse@spbo.unibo.it

\footnotetext{
${ }^{1}$ Universita' di Bologna and International Monetary Fund. I wish to thank Fabrizio Balassone, Mark De Broeck, Jiri Jonas, Manmohan Kumar, Alessandro Rebucci, and Alessandro Turrini for their comments.
} 
Contents

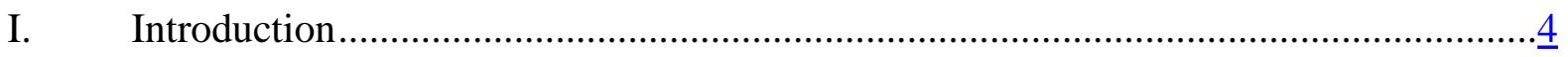

II. Review of the Literature .................................................................................

A. Fiscal Policy Rules..............................................................................

III. Methodology ............................................................................................. 10

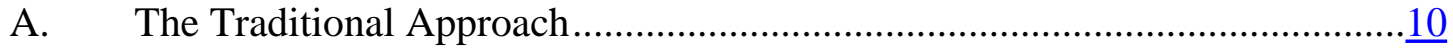

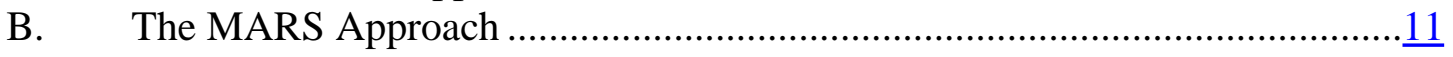

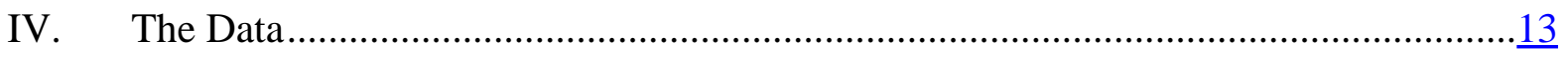

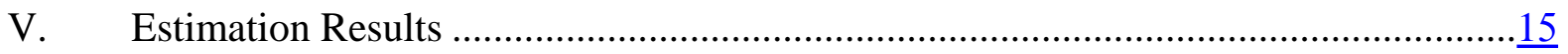

A. Robustness Checks....................................................................... $\frac{19}{31}$

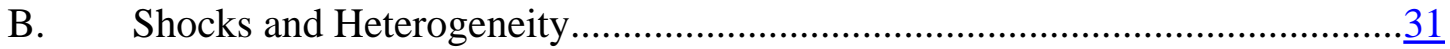

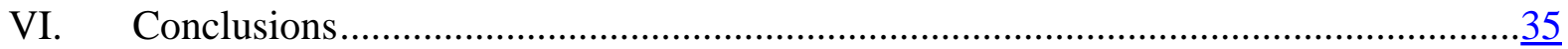

Tables

1. List of Countries in the Sample ............................................................................16

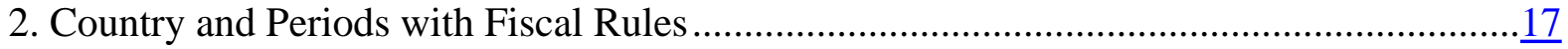

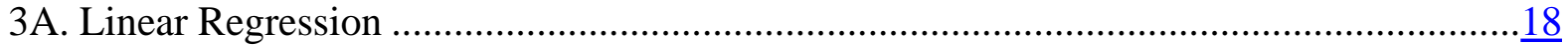

3B. MARS Regression............................................................................................. $\frac{18}{19}$

4A. A Linear Regression with Fixed Effects ............................................................... 19

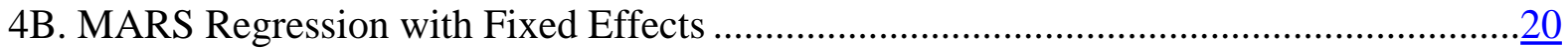

5A. Linear Model with Fixed Effects and Fiscal Rules ...................................................

5B. MARS Model with Fixed Effects and Fiscal Rules ................................................21

6A. Linear Model with Fixed Effects, Fiscal Rules, and Institutions..................................25

6B. MARS Model with Fixed Effects, Fiscal Rules, and Institutions, No Interactions ...........26

7A.Linear Model with Fixed Effects, Fiscal Rules, and Institutions with Gap Interactions ...229

7B. MARS Model with Fixed Effects, Fiscal Rules, Institutions, and Interactions ................. $\underline{30}$

8A. Linear Model, Developing Countries, Fixed Effects …...............................................

8B. Linear Model, Developed Countries, Fixed Effects.....................................................

9A. MARS Model, Developing Countries, Fixed Effects .................................................34

9B. MARS Model, Developed Countries, Fixed Effects..................................................... 
Figures

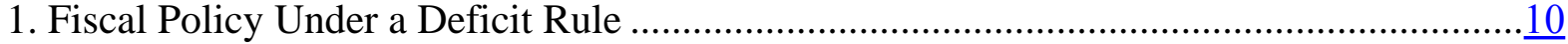

2. MARS Coefficients in the Benchmark Model................................................................19

3. MARS Coefficients with Fixed Effects ..................................................................20

4. MARS Coefficients with Fixed Effects and Fiscal Rules...........................................22

5. MARS Model with Fixed Effects, Fiscal Rules, Institutions: No Interactions...................27

6. MARS Model with Fixed Effects, Fiscal Rules, and Interactions ...................................

7. Histogram of Output Gap.......................................................................................

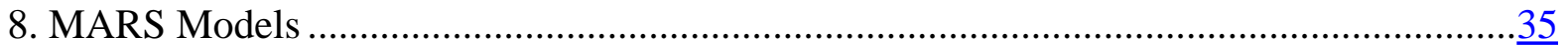




\section{INTRODUCTION}

Is fiscal policy procyclical? And if so, where and when is it the case? And is it because of weak institutions, borrowing constraints, fiscal rules, or bad/good shocks? This paper addresses these questions empirically.

Procyclical fiscal policies, that is policies that are expansionary in booms and contractionary in recessions, are generally regarded as potentially damaging for welfare: they raise macroeconomic volatility, depress investment in real and human capital, hamper growth, and harm the poor (Serven, 1998; World Bank, 2000; IMF, 2005; IMF 2005b). If expansionary fiscal policies in good times are not fully offset in bad times, they may also produce a large deficit bias and lead to debt unsustainability and eventual default.

Many empirical studies have found that discretionary fiscal policy tends to be procyclical, across different countries, notably developing countries, and time periods. This finding has "puzzled" macroeconomists, since it does not square with the common wisdom that governments should borrow in "bad times" when revenues shrink and "social" spending rises, and repay debt in good times. More specifically, procyclical fiscal policy is at odds with both the neoclassical notion that tax policy should be used to smooth tax distortions and expenditures over the business cycle-provided shocks to the tax base or spending are temporary - and the Keynesian notion that taxes and expenditures should try to dampen, rather than exacerbate, business cycle fluctuations.

While the literature has suggested a number of plausible explanations for procyclical policies, ranging from weak institutions, corruption, and asymmetric information, "voracity effects" and common pool problems, the presence of fiscal rules and borrowing constraints, it has not adequately addressed most of the questions raised above.

The aim of this paper is, therefore, to assess the role of shocks, rules, and institutions as possible sources of procyclicality. I employ both parametric and nonparametric techniquesMultiple adaptive regression splines (MARS) - to a large panel of countries in order to approximate and estimate the "true" functional form of an (otherwise standard) fiscal policy reaction function. The primary balance-to-GDP ratio is a (possibly nonlinear) function of the public debt-to-GDP ratio and the "output gap," as well as of other variables describing the presence of constraints on fiscal policy (fiscal rules or borrowing constraints) and the quality of institutions.

There are four main findings. The first concerns the role of shocks. The policy reaction to the business cycle is different depending on the state of the economy: fiscal policy is "acyclical" during bad times, while it is largely procyclical during good times.

The second result concerns the role of fiscal rules, such as limits on the deficit, borrowing or spending, and so-called fiscal responsibility laws. Evidence suggests that these constraints reduce the deficit on average. Contrary to some theoretical studies, fiscal rules also seem to enhance, rather than weaken, countercyclical policy. However, the evidence also suggests that fiscal frameworks may be themselves determined by “deeper” institutional variables, so 
that they do not significantly affect policy when the quality of institutions is controlled for. Similarly, I do not find empirical support for borrowing constraints as a possible cause of procyclicality, specifically during the down phase of the cycle.

Third, strong "institutions" are found to reduce the deficit bias on average. However, the effect on procyclicality is ambiguous: for many, but not all indicators, better institutions are associated with lower procyclicality in good times, when the problem is more acute; however, the reverse often occurs in bad times. The desirable effects of institutional quality also appear subject to decreasing returns. The effect is typically strong when institutions improve from a very weak position, but levels off when institutions are sufficiently strong.

Fourth, my evidence is consistent with the conjecture that the observed difference between developing and developed countries in how fiscal policy reacts to shocks is at least in part due to different shocks, rather than different behavior. For both groups, policy is largely acyclical in bad times and procyclical in good times. The main difference is that "bad times" in developing countries are much worse than "bad times" in industrialized countries, so that procyclical behavior occurs for a larger range of bad states. Once in "good times," however, fiscal policy is actually more procyclical in developed economies.

Before I proceed, let me clarify some terms used in the paper. Fiscal policy is defined countercyclical if the (estimated) semi-elasticity of the primary balance-to-GDP ratio with respect to the output gap is strictly positive, so that the primary balance rises more than output in booms, and falls more than output in recessions (see Alesina and Tabellini (2005), and, for a related critical discussion , Kaminsky and others (2004)). A procyclical policy is similarly defined as a negative response of the primary deficit/GDP ratio to the output gap. Finally, a policy is called "acyclical" when the semielasticity is zero, so that the surplus rises or falls in proportion with GDP when the gap rises or falls. ${ }^{2}$

The plan of the paper is as follows. Section II puts the present paper in the context of the relevant literature; Section III describes MARS, the nonlinear estimation technique employed, and Section IV presents the data set. The results of the linear and nonlinear estimation techniques are discussed in Section V. Section VI briefly considers the issue of different fiscal responses in developing and developed countries, while Section VII concludes.

\footnotetext{
${ }^{2}$ During a contraction, the operation of automatic stabilizers would have the fiscal position to deteriorate, since the expenditure-to-GDP ratio then typically rises more rapidly than the revenue-toGDP ratio (see van der Noord, 2000; Bouthevillain and others, 2001; and IMF, 2005). If instead the fiscal position does not deteriorate during a contraction, it can be infferred that tax rates were raised or expenditures reduced. Thus, had we focused on the discretionary nature of fiscal policy, we would have considered this case as "weakly procyclical."
} 


\section{REVIEW OF THE LITERATURE}

Gavin and Perotti (1997) observed that budget deficits in Latin America in 1970-95 largely failed to respond to economic growth, suggesting that discretionary policy was used in a procyclical fashion, so as to offset automatic stabilizers (for example, raising expenditures to offset revenue windfalls in good times). They suggested that the explanation might relate to the fact that capital flows are also strongly associated with the business cycle: they tend to be high in good times and low (or negative) in bad times. The idea that developing countries may face borrowing constraints, in bad times but not in good times, is also supported by the evidence presented in Kaminsky and others (2004). In particular, they show that credit ratings for Latin American sovereign issuers tend to be good during periods of high growth and bad during recessions.

Other studies present evidence of procyclicality for developed countries as well, albeit to a lesser extent. For example, IMF (2005) finds that a one point increase in the output gap (defined as the percentage deviation of actual from potential output) in these countries is on average associated with an improvement of the overall deficit ratio by 0.3 percent in industrial countries. Given the evidence that automatic stabilizers improve overall budget performance by $1 \frac{1}{2}$ percentage point (van den Noord, 2000; Bouthevillain and others, 2001; IMF, 2004), this result suggests that discretionary policy has been used procyclically in developed countries as well.

Another finding closely related to this paper is that fiscal policy appears asymmetric over the business cycle in developed economies. For instance, European Commission (2001) finds that in 1970-2000 European countries let the overall deficit widen in downturns, but failed to reduce it in upturns. Hercowitz and Strawczynski (2004) find a similar "cyclical ratcheting” effect for government spending in OECD countries. Balassone and Francese (2003) and Buti and Sapir (1998) confirm these results for OECD and EU countries, respectively. However, attempts to attribute this asymmetric behavior to the working of the Stability and Growth Pact-with its 3 percent ceiling on the deficit output ratio possibly constraining fiscal policy only in good times - has not found much empirical support (see IMF, 2003; and Balassone and Francese, 2004). ${ }^{3}$

Unlike this paper, these studies employ an ad-hoc procedure distinguishing positive from negative gaps (or growth rates) and estimate separate coefficients for the response of the primary balance. This procedure is likely to induce a bias in the estimates as discussed below. Also unlike this paper, most of the studies above focus on either the developed or developing economies, mostly emerging markets, and generally offer no attempt to generalize their findings on the presumption that fiscal authorities in developing and developed countries behave differently.

\footnotetext{
${ }^{3}$ These results are not uncontroversial: Melitz (2002) for example concludes that European countries followed mildly countercyclical policies.
} 
The theoretical literature has proposed several explanations of the procyclicality "puzzle," mostly related to the idea of weak political institutions. Lane and Tornell (1999) discuss a "voracity" effect that may take place in economies lacking strong legal and political institutions. In such circumstances, a windfall in revenue exacerbates the struggle for fiscal redistribution, as each interest groups tries to appropriate its share without fully internalizing the consequence of its own demand on general taxation. Lack of coordination, in this version of the familiar common pool problem, is ultimately responsible for a more-than-proportional increase in spending. The same mechanism, however, does generate a more than proportional fall in redistribution when revenues fall.

Talvi and Vegh (2005) present an optimizing behavior model that introduces a political distortion, which raises the cost of running surpluses in good times. They show that, a result, the government will choose to cut tax rates in good times to fend-off spending pressures in good times. Although this distortion is not derived explicitly, it is supposed to capture political pressures and weak institutions.

Alesina and Tabellini (2005) suggest an explanation for procyclical fiscal policy based on electors' mistrust of corrupt politicians. Voters are not fully informed on the government transfers and borrowings, but observe output accurately. Since they cannot prevent the government from borrowing in good times, they will demand lower taxes and more consumption in such times, as they (correctly) anticipate that, otherwise, windfall revenues will be dissipated through unproductive rents. By the same token, however, voters will be willing to accept higher taxes and lower consumption when observing low output, so that government borrowing will decline in bad times.

While these models suggest explanations in terms of the role of weak institutions, they cannot account for the state-dependent nature of the policy response found in this paper, namely the fact that the same government/country may pursue a procyclical policy in good times and a counter or acyclical policy in bad times.

Guerson (1993) proposes an interesting model that can combine elements of both the “institutions," and "rule/constraints” view. In an overlapping generation model where the government acts as a benevolent planner, he shows that a procyclical policy can be socially optimal when the government cannot commit not to default on its debt. Since the temptation to default is higher in bad times, the risk premium is also higher in such states. Thus, following a negative shock, the government doe not fully accommodate it by borrowing, but partially reduces government spending. This mitigates the rise in the interest premium and the fall in future consumption. 


\section{A. Fiscal Policy Rules}

"Fiscal rules" come in a large variety, encompassing borrowing, spending and debt limits. ${ }^{4}$ However all can be thought of as disciplining devices against politically motivated deficit "bias". The idea that such rules may induce procyclicality goes back to the debate on the Stability and Growth pact (see Buiter, Corsetti, and Roubini, 1993). In a simple BarroGordon type of framework developed in a related paper, see Manasse (2005), I discuss the idea that most fiscal rules involve a trade-off between the benefits of reducing the average deficit bias - which is assumed to be politically motivated and constant over time-and the costs of foregone stabilization.

In particular, that paper describes a situation where a (myopic) government is subject to a political bias toward excessive deficit. It chooses fiscal policy under a self-imposed (statecontingent) deficit rule: when the deficit-to-output ceiling is exceeded, the government, with a given probability, pays a pecuniary (or reputational) penalty proportional to the excess deficit. Essentially, the government has to decide whether or not to abide with the rule, weighting the benefits of stabilization (which are higher in bad times) against the (political) costs of breaching the rule.

The optimal fiscal policy reaction function for this case turns out to be non linear: it is depicted in Figure 1 below. In good times (gap above $e_{1}$ in the Figure), the deficit-output ceiling is not binding and the primary balance responds countercyclically: the balance rises more than proportionately when GDP rises, moving along the bold, positively-sloped line. In moderately bad times (between $e_{0}$ and $e_{1}$ ), the constraint on the deficit-output ratio becomes binding. The government, in order to avoid the sanction, optimally chooses to keep the deficit ratio as close as possible to the limit, moving along the constraint (the flat dotted line): any worsening (improvement) of output is met by a proportional fiscal contraction (expansion), so that the deficit ratio remains constant. According to my definition, fiscal policy in this range is acyclical. Finally, during economic slumps (below $e_{0}$ ), the cost of foregoing stabilization exceeds the expected penalty from breaking the rule, so that the government chooses to violate the rule, and runs a countercyclical policy, increasing the deficit ratio when output falls and reducing the ratio when output rises (it moves along the straight segment on the left of the Figure).

In this framework, it is easy to show that when policies are based on expected future shocks, the effect of a fiscal rule is to reduce the average deficit ratio in all states of nature, the more so the lower is the volatility of shocks (see Manasse, 2005).

Do fiscal rules necessary entail a-(or pro) cyclical policies? Most (poorly designed) rules probably do, but well (optimally) designed ones do not. In Manasse (2005), I show that rules

\footnotetext{
${ }^{4}$ I abstract from the vast literature that considers fiscal (or monetary) feedback rules, where a control variable, say the tax rate, is set as a continuous function of a state variable, say the debt-GDP ratio, and the resulting dynamics and welfare properties of the equilibrium are studied, see for example Schimitt-Grohe and Uribe (2004).
} 
that penalize deficits and reward surpluses, irrespectively of the state of the economy, can eliminate the deficit bias without giving rise to procyclicality. For example, allowing the authorities to accumulate "credits" when running surpluses to be spent for running deficits, say by means of a stabilization fund, would achieve this objective (see also Casella, 1999, for a related idea in terms of tradable deficit permits).

This outline may be even more likely in a dynamic context: if policymakers are subject to an electoral distortion and prefer current to future consumers (voters), well-designed fiscal rules may reduce the need for future increase in tax rates, thereby allowing policymakers to better smooth tax distortions over time, lessen procyclicality and improve welfare, see Tanner (2005). In summary, fiscal rules should be associated with a lower average deficit bias; the effect on procyclicality is, however, ambiguous and depends on the actual design of the rule and the time horizon of policymakers.

Clearly, any type of state-contingent punishment, such as widening spreads on external debt in bad times, would provide similar incentives as a self-imposed fiscal rule. There is plenty of evidence suggesting that spreads on external debt tend to widen in recessions, see for example Kaminsky and others, 2004. Yet borrowing constraints differ from fiscal rules in one important aspect: a country may not have the option to violate an externally imposed constraint. During a crisis $\left(e<e_{0}\right)$ it may not be able to finance a fiscal expansion, and may be forced to move along the dotted constraint line. ${ }^{5}$ Empirically, both types of constraints should be associated with a "flat" segment of the fiscal reaction function. Providing evidence for and deriving the precise characterization of such a flat segment in bad times is one of the main contributions of the paper.

\footnotetext{
${ }^{5}$ I am indebted to Alessandro Rebucci for a useful discussion on this point
} 
Figure 1. Fiscal Policy Under a Deficit Rule

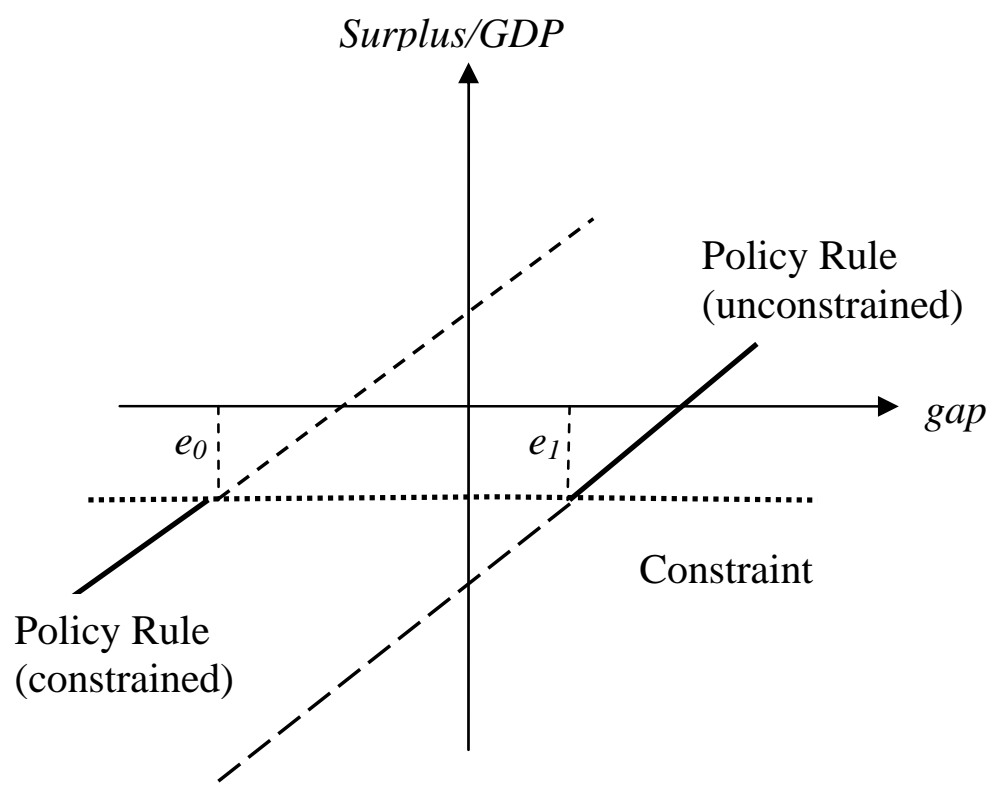

Source: Manasse (2005)

\section{METHODOLOGY}

In this section, I briefly discuss the traditional approach to estimating fiscal reaction functions and its limits. I then discuss the nonlinear and nonparametric approach employed in the paper.

\section{A. The Traditional Approach}

Typically, a simple linear regression such as the one specified in equation (1) below is estimated for a panel of countries, $v=1 \ldots N$ observed at time $t=1 \ldots T$. The equation relates the primary (or total) surplus, $S$, or its components, ${ }^{6}$ in percent of GDP (or potential output) to the output gap (or the rate of GDP growth), Gap, controlling for the debt-GDP ratio, $D$, and the lagged dependent variable:

$$
S_{v, t}=a_{0}+a_{1} \operatorname{Gap}_{v, t-1}+a_{2} \operatorname{Debt}_{v, t-1}+a_{3} S_{v, t-1}+a_{4} X_{v, t-1}+u_{v, t} \quad v=1 \ldots N, \quad t=1 \ldots T
$$

Where $u$ is an i.i.d. disturbance. Additional controls, $X$, are often introduced to capture heterogeneity (fixed effects), as well as proxies for institutional quality, exchange rate regimes, corruption and other variables. Typically, these additional variables appear as dummy intercepts, and occasionally they are interacted with output gaps (or growth rates). Some studies, for instance Hercowitz and Strawczynski (2004); and Balassone and Francese (2003), also test for different coefficient for positive and negative output gaps (or growth

\footnotetext{
${ }^{6}$ These are typically expressed as a ratio of (actual or potential) output.
} 
rates). Typically, due to the poor fit of the joint estimation and the heterogeneity of countries, the exercise is repeated for different sub samples and/or time periods (developing and developed countries, before-after Maastricht). Alternatively (Alesina and Tabellini, 2005), equation (1) is estimated country by country, and the estimate of parameter $a_{1}$ is then regressed on measures of institutional quality, in order to establish a relationship between procyclicality and weak institutions. As in our definition above, these authors interpret $a_{1}<0$ as evidence of procyclical policy: the primary balance-to-GDP ratio falls when the output increases relatively to potential output.

Equation (1) was first introduced by Bohn (1988) as a transformation of the government budget constraint, in order to test for government solvency, which requires that $a_{2}>0$. Since then this specification has been widely (and possibly incorrectly) interpreted as a behavioral equation, describing the (presumably optimal) response of policy to the business cycle.

Implicit in the linear representation (1) is the assumption that coefficients are stable across all levels of the explanatory variables, for example that the balance responds in the same manner to output shocks irrespectively of the state of the economy. Suppose, however, that Figure 1 above represents the "true" reaction function. If a line were fitted to the data points, the estimated slope $a_{1}$ could be any number between the positive slope of the reaction functions or the zero slope of the constraint, depending on the country's realizations of output gaps during the sample period. Moreover, even if all countries were indeed characterized by the same, but nonlinear reaction function, the assumption of linearity may artificially create "heterogeneity" in the response of the balance to the output gap (or debt variables): different countries would appear to have different $a_{1}$ 's only because they experience different Gap realizations. Indeed this paper finds evidence that this is exactly what happens when linearity is imposed.

Assuming that the reaction function has different slopes for a positive/negative Gap may improve the model specification, but only insofar the "true" break points, $e_{0}, e_{1}$, are close to zero, which may not be the case. The idea next is to let the data determine the functional form of the fiscal reaction function.

\section{B. The MARS Approach}

This section briefly describes the Multiple adaptive regression spline ${ }^{7}$ (MARS) approach of Friedman, 1991. Unlike classic regression analysis, here we start from the presumption that the functional form describing the relationship between the independent and dependent variables is unknown. The algorithm provides a fruitful way to approximate this relationship and select the "relevant" variables, by specifying both their functional form as well as their interactions.

\footnotetext{
${ }^{7}$ The estimation employs the MARS software developed by Salford Systems.
} 
The approach models the dependence of a response variable, $y$, on a set of $n$ predictor variables, $\mathbf{x}=\left(x_{1}, . . x_{n}\right)$ given data on the realizations of these variables $\left\{y_{t}, x_{1 t} \ldots x_{n t}\right\}_{t=1, \ldots T}$. The data is thought to be generated by an unknown function $f$,

$$
y=f\left(x_{1}, x_{2}, \ldots x_{n}\right)+u
$$

subject to noise, $u$, and the aim is to find a "good" approximation, $\hat{f}$. The MARS algorithm (see Friedman, 1991, for a comprehensive exposition) assumes separability, in that this function can be written as the sum "individual effects", $f_{i}\left(x_{i}\right)$, plus two-variable "interactions," $f_{i j}\left(x_{i}, x_{\mathrm{j}}\right)$, plus three-variable interactions and so on with interactions of higher order:

$$
\hat{f}(\mathbf{x})=a_{0}+\sum_{i} f_{i}\left(x_{i}\right)+\sum_{i j} f_{i j}\left(x_{i}, x_{j}\right)+\sum_{i j k} f_{i j}\left(x_{i}, x_{j}, x_{k}\right)+\ldots
$$

In turn, the first component is approximated by a piece-wise linear (spline) representation:

$$
f_{i}\left(x_{i}\right)=\sum_{m} a_{m}\left( \pm \max \left(x_{i}-t_{m}^{i}, 0\right)\right)
$$

so that each function $f_{i}$ is the sum of pairs of linear segments ("basis functions") joined at "knots" $t_{m}^{i}$, each non zero on one side of the knot.

For example, suppose that a univariate function $f(x)$ can be approximated by a simple "spline," a straight line whose slope steepens when the "knot" $t$ is reached:

$$
\begin{aligned}
& f(x)=b_{0}+b_{1} x+u \quad x \leq t \\
& =c_{0}+c_{1} x+u \quad x>t ; \\
& \text { with } b_{0}>c_{0}>0, c_{1}>b_{1}>0, t=\left(b_{0}-c_{0}\right) /\left(c_{1}-b_{1}\right)>0
\end{aligned}
$$

The MARS representation (4) of the previous expression would be:

$$
f(x)=a_{0}+a_{1} \max (t-x, 0)+a_{2} \max (x-t, 0)+u, a_{1}=-b_{1}, a_{2}=c_{1}, a_{0}=b_{0}-a_{1} t
$$

Similarly, the two-way interaction function $f_{i j}$ are modeled as the products of "basis functions," $\pm \max \left(x_{i}-t_{m}^{i}, 0\right) *\left( \pm \max \left(x_{j}-t^{j}{ }_{m}, 0\right)\right)$ and so on.

Finding the "best knot" in a simple univariate regression such as (5) is not difficult: one may simply examine a large number of candidates and select the regression which delivers the best $R^{2}$. Finding the best pair of interactions with more than one regressor is already much more complicated. ${ }^{8}$ Many additional computations would be required if the location of the knots were unknown. The MARS algorithm proceeds as follow, see De Veux and Ungar (1994):

\footnotetext{
${ }^{8}$ Suppose that the location of knots was predetermined (say above/below the mean value for each regressor) and we wanted to consider 10 regressors. We would have to choose among $2^{10}=1024$ possible regions.
} 
- $\quad$ Fit a model with only the constant term.

- $\quad$ For each variable $x_{i}$, and each possible realization, find the best knot $t_{i}$ and divide the data in two parts, on either side of the knot: then fit the response using a pair of linear functions , each non zero on one side of the not (the "basis" functions).

- $\quad$ Add each basis function to the model in turn, and select the basis function that most reduces the mean squared error (MSE). The new model becomes the constant plus the "best" basis function.

- $\quad$ After one variable has been selected, select a new split on a subsequent variable in one of the following two ways. The new function can be entered either as an interaction term (so the new split depends on the previous one, and the sample space is split on just one side of the previous knot), or as a new variable (that is, the previous split is ignored, and the entire sample space is split on the new knot).

- $\quad$ Repeat steps 3 and 4 and add the next-best basis function to the model, either as an additional variable or as an "interaction term," on the basis of the MSE criterion, until degrees of freedom are exhausted.

- $\quad$ Prune back the over-fitted model, by deleting each variable in turn, starting from the "least important" (the one whose exclusion raises the mean square error by the least), until only the constant term is left.

- $\quad$ Choose the model which minimize the mean squared error corrected for the number of "variables" (basis functions).

The MARS algorithm follow a logic similar to the Classification and Regression Tree algorithm (see Breiman and others, 1984; and Manasse and Roubini, 2005 for a recent application to sovereign default). It provides a search procedure that selects variables, looks for nonlinearities, threshold effects and possible high-order interactions among variables. Note that MARS does not exclude a linear structure, but tests for it. Moreover, its forward and backward nature protects against over-fitting. The risk of obtaining a perfect fit to the sample data and poorly performing out-of-sample is avoided by the "cross validation" procedure: at each stage, the MSE of a candidate model is evaluated on a subset of sample observations that were not used in the estimation. An important property of adaptive splines is their capacity to effectively deal with heterogeneity and "outliers": by isolating a local "sharp structures," the fit in other regions of the sample space is unaffected (Friedman, 1991). This property will turn out to be quite important in what follows.

\section{THE DATA}

The sample consists of an unbalanced panel of annual observations for 49 emerging and industrial countries (Table 1) for the period 1970-2004. Among fiscal variables, the Primary Balance refers to the General Government and is obtained from the World Economic Outlook (WEO) database. Similarly, IMF 2003 is the source for total general government Public Debt and the Output gap, defined as the percentage deviation of actual GDP from potential (HP filtered) output, so that a positive gap indicates that output is above trend. The Political economy variables are derived from the International Country Risk guide (ICRG). 
They include measures of social, institutional, economic and financial vulnerability (see ICRG (2005) for more details), with low values of the indices indicating poor institutions, or high vulnerability. ${ }^{9}$

An other popular data source for institutional variable is the World Bank Governance Indicators, see Kaufmann and others, 2005. Unfortunately the series are only available since 1996, so the ICRG data is used.

In order to capture the characteristics of the framework for fiscal policy, and the existence or absence of explicit constraints on its operations in particular, I construct a dummy for the presence of a "fiscal rule" in each country-year. Following Kopits and Symansky (1998), a fiscal rule is defined as a "... permanent constraint on fiscal policy, typically defined in terms of an indicator of overall fiscal performance...such as the government budget deficit, borrowing, debt, or major components thereof—often expressed as a numerical ceiling or target, in proportion of Gross Domestic Product.”

Fiscal responsibility laws are also considered providing some constraint on fiscal policy, similarly to explicit fiscal rules. Both fiscal responsibility laws and fiscal rules differ in many dimensions, see the discussion in IMF (2005): some focus on numerical targets or rules and apply to different aggregates (borrowing, expenditures, primary balance); other involve procedural and transparency requirements; additional differences involve the extent of coverage (federal, state), the presence of escape clauses, and the presence of explicit sanctions. Clearly, different policy frameworks may have different impact on fiscal policy and may be applied with more or less cogency, and thus may have more or less credibility. Moreover, poorly designed rules may aggravate procyclicality, while well-designed rules may alleviate it.

The fiscal rule indicator, described in Table 2, is admittedly quite coarse, and is based on the evidence summarized in Kopits and Symansky (1998) and IMF (2005b). However, available alternative sources lack a time dimension (i.e., we know which country has a given rule in

\footnotetext{
${ }^{9}$ The measures of "fundamental" sociological characteristics cover Internal and External Conflict, Ethnic Tensions, Religious Tensions, Military in Politics, Index of Socio-Economic Conditions, Corruption. Among those of institutions quality, the indexes describe Government Stability, Bureaucracy Quality, Law and Order, Democratic Accountability. A weighted average of these indices constitutes the Political Risk Rating index. Among indicators of economic and financial vulnerability, possibly capturing financing contraints, the Financial Risk Rating is a weighted average of several indicators (the percentage of gross foreign debt over GDP, Debt service over exports, Current Account over Exports of Goods and Services, Net International Liquidity as months of import cover and an index of Exchange rate Stability). The Economic Risk Index is built from measures of GDP per head, Real GDP growth, the Inflation rate, the General Government Budget Balance as percentage of GDP, the Current Account as Percentage of GDP. The Composite Risk Rating weight Financial, Economic and Political Risks. Finally, I also use the index of Risk Perceptions for GDP growth, Risk Perceptions for foreign Debt and for Debt Service, Risk Perceptions for Exchange Rate Stability.
} 
place, but not when it was introduced). This applies, for example, to the OECD-World Bank (2003) detailed survey on Budget Practices and Procedures.

\section{ESTIMATION RESULTS}

In this section, I present the regression results and compare the linear and MARS approaches. The main result is that the nonlinear model is a better approximation of the "true" functional form and effectively captures country-specific heterogeneous features. In particular, during normal times the fiscal response is notably procyclical, while at times of slumps it becomes acyclical.

Table 3A reports the estimation results of the linear model, equation (1), with no fixed effects. The coefficient on the (lagged) debt variable is quite small, but significant and with a positive sign — from Bohn (1989), the necessary condition for solvency is, therefore, satisfied in the sample period. The coefficient of the (lagged) output gap is significant and negative, which implies that fiscal policy has been overall procyclical in the past 30 years or so, with the primary surplus falling (and the deficit rising) as a share of GDP by roughly 1/10th of a percentage point when the output gap improved by one percentage point.

The constant term gives the mean balance when controlling for the previous period debt, gap and balance. Thus it can be interpreted as measure of the average short-term primary deficit bias (if negative): that is, the average deficit controlling for the state if the economy and other variables. The estimate shows that the average deficit bias for the entire sample period and country coverage amounts to 3.7 percent of GDP.

The nonlinear ${ }^{10}$ specification is displayed in Table 3B, where I employ the notation $(x, y)=\max (x, y)$. To facilitate the interpretation of the coefficient, Figure 2 displays the relationship between the primary balance-to-GDP ratio and each independent variable, controlling for the others ${ }^{11}$. As opposed to the linear model, the debt-to-GDP ratio does not improve the model's Mean Squared Error (MSE) and therefore is dropped by the algorithm.

${ }^{10}$ In the text, for brevity I will use the term "nonlinear" model to indicate the MARS (piecewise linear) model.

${ }^{11}$ For example the second panel on the right of Figure 2 shows that the lagged output gap (GAP1) has no effect on the primary balance until the threshold -5.49 is reached, and a negative one (coefficient -0.14 ) thereafter. PRIMBA1 denotes the lagged value of the primary balance. 
Table 1. List of Countries in the Sample

\begin{tabular}{|c|c|c|}
\hline Country & Obs & Percent \\
\hline Argentina & 15 & 1.65 \\
\hline Australia & 33 & 3.63 \\
\hline Austria & 25 & 2.75 \\
\hline Brazil & 15 & 1.65 \\
\hline Bulgaria & 15 & 1.65 \\
\hline Canada & 33 & 3.63 \\
\hline Chile & 17 & 1.87 \\
\hline China & 19 & 2.09 \\
\hline Colombia & 15 & 1.65 \\
\hline Costa Rica & 13 & 1.43 \\
\hline Côte d’Ivoire & 15 & 1.65 \\
\hline Croatia & 11 & 1.21 \\
\hline Czech Republic & 8 & 0.88 \\
\hline Denmark & 32 & 3.52 \\
\hline Ecuador & 15 & 1.65 \\
\hline Egypt & 4 & 0.44 \\
\hline France & 23 & 2.53 \\
\hline Hungary & 15 & 1.65 \\
\hline India & 15 & 1.65 \\
\hline Indonesia & 30 & 3.30 \\
\hline Israel & 15 & 1.65 \\
\hline Italy & 23 & 2.53 \\
\hline Japan & 33 & 3.63 \\
\hline Jordan & 12 & 1.32 \\
\hline Kenya & 23 & 2.53 \\
\hline Korea & 15 & 1.65 \\
\hline Lebanon & 15 & 1.65 \\
\hline Malaysia & 15 & 1.65 \\
\hline Mexico & 25 & 2.75 \\
\hline Morocco & 15 & 1.65 \\
\hline Netherlands & 23 & 2.53 \\
\hline Nigeria & 15 & 1.65 \\
\hline Norway & 27 & 2.97 \\
\hline Pakistan & 14 & 1.54 \\
\hline Panama & 13 & 1.43 \\
\hline Peru & 15 & 1.65 \\
\hline Philippines & 15 & 1.65 \\
\hline Poland & 13 & 1.43 \\
\hline Russia & 13 & 1.43 \\
\hline Singapore & 17 & 1.87 \\
\hline South Africa & 25 & 2.75 \\
\hline Spain & 23 & 2.53 \\
\hline Sweden & 23 & 2.53 \\
\hline Thailand & 9 & 0.99 \\
\hline Turkey & 18 & 1.98 \\
\hline United Kingdom & 24 & 2.64 \\
\hline Ukraine & 10 & 1.10 \\
\hline Uruguay & 35 & 3.85 \\
\hline Venezuela & 17 & 1.87 \\
\hline Total & 908 & 100.00 \\
\hline
\end{tabular}

Source: Author’s calculations. 
Table 2. Country and Periods with Fiscal Rules (in the Sample)

\begin{tabular}{lc}
\hline Country & Period \\
\hline Argentina & $2000-04$ \\
Austria & $1998-04$ \\
Brazil & $2001-04$ \\
Bulgaria & $2002-04$ \\
Canada & $1970-04$ \\
Chile & $1970-04$ \\
Colombia & $1997-04$ \\
Czech Republic & $2002-04$ \\
Denmark & $1998-04$ \\
Ecuador & $2003-04$ \\
Egypt & $1970-04$ \\
France & $1998-04$ \\
Hungary & $1990-04$ \\
India & 2004 \\
Indonesia & $1970-04$ \\
Italy & $1998-04$ \\
Japan & $1970-04$ \\
Morocco & $1970-04$ \\
Netherlands & $1970-04$ \\
Norway & $1970-04$ \\
Panama & $1998-04$ \\
Peru & $2002-04$ \\
Philippines & $1970-04$ \\
Poland & $1998-04$ \\
Russia & $2002-04$ \\
Spain & $1998-04$ \\
United Kingdom & $1998-04$ \\
Ukraine & $1998-04$ \\
\hline & $2002-04$ \\
\hline
\end{tabular}

Source: Author's calculations. 
More noticeable is the shape of the nonlinearities. The persistence effect in the balance-toGDP ratio increases when the balance improves, with the coefficient of the lagged balance increasing from 0.4 (below -5.5$)$ to $1.23(=0.44+0.79)$ above the threshold -4.23 .

Interestingly, a nonmonotonic relationship between the primary balance and the output gap is detected by MARS: during “normal times,” moderate recessions or expansions (gap above -5.5), the relationship is negative, that is, procyclical: the primary balance-output ratio falls by 0.14 percentage points when the gap rises by one percent; conversely, during periods of economic "crises"-identified as times when output falls below trend by 5.5 percent or more (gap below -5.5) — the relationship becomes flat, that is, policy is acyclical and the deficitoutput ratio is not affected by the gap.

Unlike the OLS estimates, this feature of the data will turn out to be very robust. An F test of the restrictions imposed by linearity is rejected with $\mathrm{p}=0.00000$, suggesting that the linear model is strongly rejected by the data. ${ }^{12}$

Table 3A. Linear Regression

\begin{tabular}{lcccc}
\hline Parameter & Estimate & S.E. & T-ratio & P-value \\
\hline Primary balance & 0.75 & 0.02 & 31.75 & 0.00 \\
Public debt & 0.01 & 0.00 & 3.72 & 0.00 \\
Output gap & -0.11 & 0.03 & -4.08 & 0.00 \\
Constant & -.368 & .172 & -2.14 & 0.03 \\
\hline
\end{tabular}

N. of Obs: 737; R-Squared: 0.5924 ; Adj R-Squared: 0.5907; MSE: 2.1692.

Source: Author's calculations.

Table 3B. MARS Regression

\begin{tabular}{lcccc}
\hline Parameter & Estimate & S.E. & T-ratio & P-value \\
\hline$(0,-5.03-$ Primary balance $)$ & -0.44 & 0.12 & -3.51 & 0.00 \\
$(0$, Primary balance + 4.23) & 0.79 & 0.02 & 31.08 & 0.00 \\
$(0$, Output gap + 5.49) & -0.14 & 0.03 & -4.25 & 0.00 \\
Constant & -2.45 & 0.22 & -11.21 & 0.00 \\
\hline
\end{tabular}

N. of Obs: 737; R-Squared: 0.587; Adj R-Squared: 0.585; MSE: 2.183.

Source: Author's calculations.

${ }^{12}$ Unlike the OLS model, the constant term in the MARS specification is not readily interpretable, as it is a linear combinations of the "true" constant term and the threshold coeffcients, see the example in (6). 
Figure 2. MARS Coefficients in the Benchmark Model
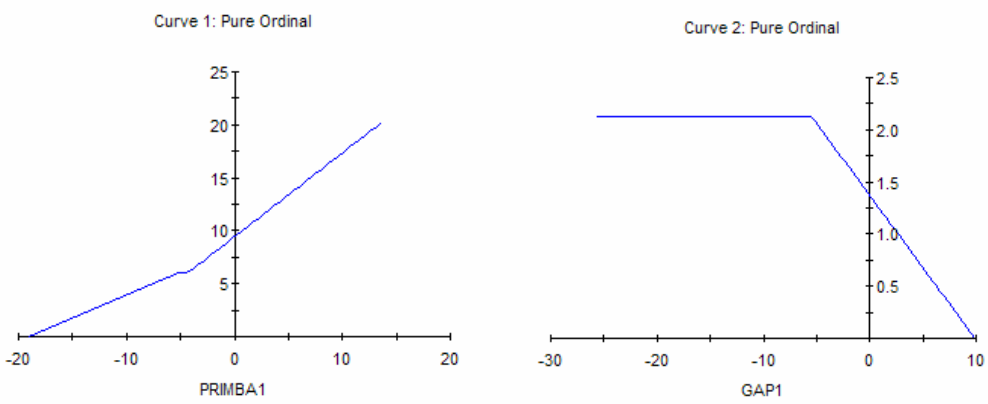

\section{A. Robustness Checks}

\section{Fixed Effects}

A simple way to account for heterogeneity is to add country-fixed effects ${ }^{13}$ (see Tables 4 and Figure 3 ). In the linear model, fixed effects improve the regression fit (see the adjusted $\mathrm{R}^{2}$ ), without affecting the significativity of the regressors. The OLS point estimates, however, change dramatically: the primary balance now shows a much stronger dependence on the debt-output ratio, whose coefficient doubles, while the coefficient of the output gap is halved. The average "deficit bias," constant term is also sensibly reduced, to $1 \frac{1}{2} 2$ percentage points of GDP.

It is well known that fixed effects induces a bias in OLS estimates when a lagged dependent variable appears as a regressor: the lagged dependent variable becomes correlated with the disturbance term, even if the latter is serially uncorrelated. However, the following considerations suggest that this is probably not the reason for the unstable OLS estimates.

Table 4A. A Linear Regression with Fixed Effects

\begin{tabular}{lcccc}
\hline Parameter & Estimate & S.E. & T-ratio & P-value \\
\hline Primary balance & 0.62 & 0.03 & 20.83 & 0.00 \\
Public debt & 0.02 & 0.00 & 4.98 & 0.00 \\
Output gap & -0.06 & 0.03 & -2.24 & 0.03 \\
Constant & -1.50 & 0.78 & -1.92 & 0.05 \\
\hline
\end{tabular}

N. of Obs: 737; R-Squared: 0.63; Adj R-Squared: 0.60; MSE: 2.13.

Source: Author's calculations.

\footnotetext{
${ }^{13}$ In terms of equation (1) this implies that the error term is assumed $u_{v t}=e_{v}+\varepsilon_{v t}$.
} 
Table 4B. MARS Regression with Fixed Effects

\begin{tabular}{lcccc}
\hline Parameter & Estimate & S.E. & T-ratio & P-value \\
\hline Constant & -3.63 & 0.25 & -14.68 & 0.00 \\
(0, Primary balance +4.94$)$ & 0.80 & 0.03 & 24.85 & 0.00 \\
$($ 0, Primary balance -4.62$)$ & -0.45 & 0.10 & -4.31 & 0.00 \\
$(0$, Public debt -29.00$)$ & 0.01 & 0.00 & 4.22 & 0.00 \\
$(0$, Output gap +5.30$)$ & -0.10 & 0.03 & -3.20 & 0.00 \\
\hline
\end{tabular}

N. of Obs: 737; R-Squared: 0.62; Adj R-Squared: 0.61; MSE:

Source: Author's calculations.

Figure 3. MARS Coefficients with Fixed Effects
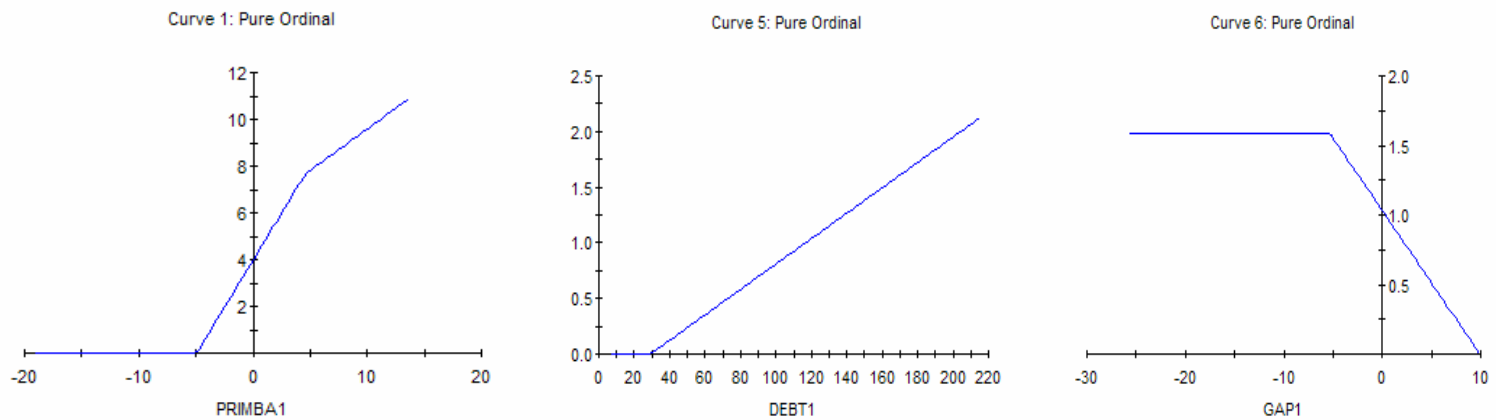

When fixed effects are introduced in the non-linear specification, the coefficient on the output gap is remarkably little affected, and so is the critical threshold (-5.5) starting from which the slope becomes negative (Table $4 \mathrm{~b}$ and Figure 3 ).

This suggests that the instability of the OLS estimates cannot be attributed to a bias induced by fixed effects. The MARS algorithm, however, now captures other interesting relationships. First, the functional form of the persistence effect. The lagged balance now appears to affect the current balance only above -5 percent of GDP threshold (left panel in Figure 3), and the relationship flattens out above surpluses of 5 percent. More interestingly, the government debt-to-GDP ratio now features significantly in the model, and exhibits a positive sign: however, this stabilizing effect appears only when the debt ratio is above the threshold of 30 percent.

An F-test continues to reject the linear restrictions imposed by the OLS model, with $p$ value $p=0.0000$

\section{Fiscal Rules}

Next, I add the fiscal rule dummy to both models with fixed effects, see Tables 5 and Figure 4. As described in the previous section, the presence of a fiscal rule is expected to 
have the following effects: on average it should raise the average balance; also, fiscal rules could raise or lower procyclicality, depending on their design.

Table 5A. Linear Model with Fixed Effects and Fiscal Rules

\begin{tabular}{lcccc}
\hline Parameter & Estimate & S.E. & T-ratio & P-value \\
\hline Primary balance & 0.61 & 0.03 & 20.24 & 0.00 \\
Public debt & 0.02 & 0.00 & 5.10 & 0.00 \\
Output gap & -0.09 & 0.03 & -2.91 & 0.00 \\
Fiscal Rule & 0.66 & 0.29 & 2.30 & 0.02 \\
Gap_fiscal rule & 0.13 & 0.07 & 1.81 & 0.07 \\
Constant & -1.56 & 0.78 & -2.01 & 0.04 \\
\hline
\end{tabular}

N. of Obs:737; R-Squared: 0.63; Adj R-Squared: 0.61; MSE: 2.12.

Source: Author's calculations.

Table 5B. MARS Model with Fixed Effects and Fiscal Rules

\begin{tabular}{lcccc}
\hline Parameter & Estimate & S.E. & T-ratio & P-value \\
\hline Constant & -3.71 & 0.24 & -15.14 & 0.00 \\
$(0$, Primary balance + 4.94) & 0.79 & 0.04 & 21.27 & 0.00 \\
& & & & \\
$(0$, Primary balance - 3.97) & 9.39 & 3.02 & 3.11 & 0.00 \\
$(0$, Primary balance - 4.16) & -12.20 & 3.61 & -3.38 & 0.00 \\
$(0$, Primary balance - 5.16) & 2.60 & 0.75 & 3.46 & 0.00 \\
$(0$, Public debt - 29.00) & 0.01 & 0.00 & 4.63 & 0.00 \\
$(0$, Output gap + 3.73) & -0.10 & 0.04 & -2.35 & 0.02 \\
$(0$, Output gap - 3.28) & -14.99 & 5.51 & -2.72 & 0.01 \\
$(0$, Output gap - 3.45) & 44.83 & 14.06 & 3.19 & 0.00 \\
$(0$, Output gap - 3.57) & -30.20 & 8.99 & -3.36 & 0.00 \\
\hline
\end{tabular}

N. of Obs: 737; R-Squared: 0.629; Adj R-Squared: 0.622; MSE: 2.08

Source: Author's calculations. 
Figure 4. MARS Coefficients with Fixed Effects and Fiscal Rules
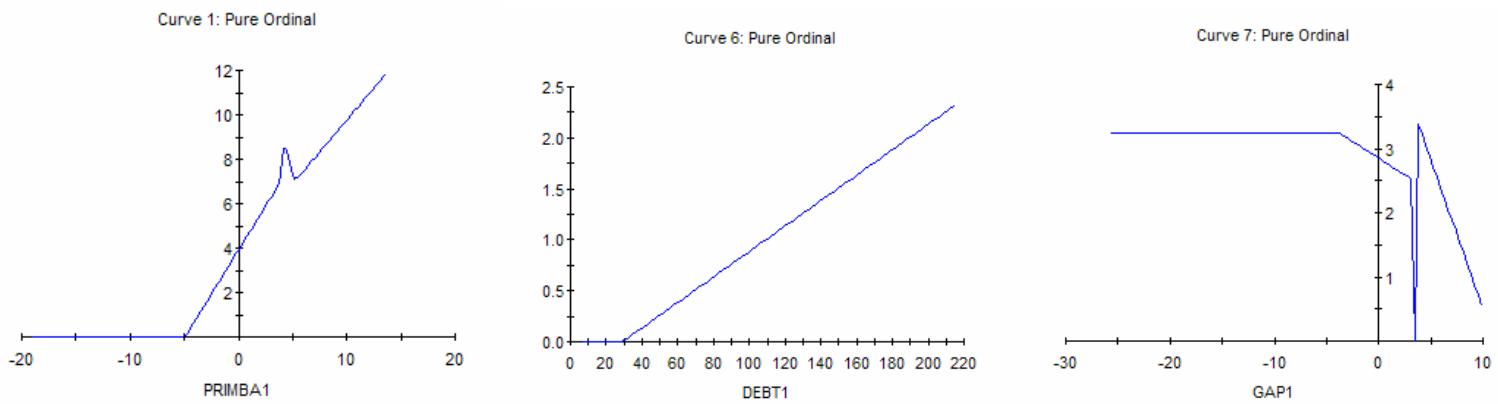

In order to capture this second effect in the linear model, I follow the standard practice of allowing for an interaction term, Gap_fiscal rule.

In the linear model, the fiscal rule dummy variable (in levels) is significant and has the expected positive sign, implying that countries with a fiscal rule experience a deficit bias that is on average 0.66 percentage points of GDP lower than those without one. The interaction term is also significant, and has a positive sign, so that, somewhat surprisingly, fiscal rules are on average associated with a more counter-cyclical policy. Taking this result at face value, fiscal rules are associated not only with more prudent policies, but also with more “stabilizing” ones.

The inclusion of the fiscal rules dummy slightly improves the regression fit, while leaving the coefficients of the gap and debt and lagged balance variables relatively unaffected.

Interestingly, in the MARS model the fiscal rule dummy does not enter significantly, in either level or interaction. This suggest that the flexible functional form provided by MARS indeed may capture some of the heterogeneity associated with different fiscal frameworks.

The functional form of the relationships between the balance ratio and the output gap is now "spelled out" in more detail. As before, fiscal policy appears acyclical when the output gap is low (now below -3.73), and it becomes procyclical (with a coefficient of -0.10) between this threshold and a positive gap of 3.28. During very good times, gaps above 3.57, the policy becomes strongly procyclical, with a coefficient of -0.46 (obtained summing up previous coefficients (see also Figure 4). The functional form now identifies a local outliers, when the gap is close to $3 \frac{1}{2}$ percent; however, the fit in other regions is not affected. The linearity restrictions are again rejected with $\mathrm{p}$-value $=0.0000$.

\section{Institutions}

I now repeat the previous experiment adding the proxies for institutional quality and vulnerability decribed above. In the linear model this is accomplished by introducing the dummy variables both in levels and interacted with the lagged output gap. It useful to 
consider first only the effect of the level dummies, thus looking at the implications for the deficit bias, and later discuss the gap interaction effects, describing the consequences for procyclicality.

\section{No Interactions}

The introduction of the new set of institutional dummies in the linear model does not significantly affect the coefficients of the debt and lagged balance ratios, nor that of the output gap. The latter remains significant and negative, thus displaying procyclical behavior. Among the newly added variables, the index of Government Stability and the of (lack of) Religious Tensions are significant and with the expected positive sign, so that better institutions are associated to higher average balances (see Table $6 \mathrm{~A}$ ). The same applies to improvements in the risk perception on GDP growth variables, which enter significantly and with a positive coefficient. The fiscal rule variables, however, become insignificant when the new variables appear in the regressions, which may suggest that appropriate fiscal frameworks are themselves determined by “deeper” institutional variables .

The MARS model displays similar, but not identical results (see Table 6B and Figure 5). The pattern of procyclicality is largely unaffected: policy is acyclical during recessions-here identified as gaps below 2 percent-and procyclical afterwards. However, the response of the balance to the debt also appears non monotonic, capturing, in particular, episodes when the debt-to-GDP ratio is very high (around 90 percent, between 100 and 120, and above 145 percent, respectively) and destabilizing responses of the balance to the debt are present (i.e., the slope turns positive).

Only two institutional variables appear to contribute to the model's specification: the index of Religious Tension (RT) and that of Bureaucratic Quality (BQ). The former reduces the deficit bias (i.e., has a positive effect on the balance), similarly to the linear model, but only when religious tensions are very low (the index is above 5). Conversely the Bureaucratic Quality index has the "wrong” sign, as it appears to raise the deficit bias, but only when the index is sufficiently high. A possible explanation is that very high bureaucratic quality typically goes hand-in-hand with very low spreads. ${ }^{14}$

Similarly to the linear model, the fiscal rule variables are not significant when institutional variables are included.

\footnotetext{
${ }^{14}$ Celasun, Debrun, and Ostry (2005) note that while weak institutions make governments, on average more willing to implement bad fiscal policies — so that one would expect to find a positive coefficient - they also make governments less able to implement bad policies, since the cost of borrowing, and the surplus required to finance a given amount of debt rise both as institutional quality worsens (implying a negative coefficient).
} 


\section{Interactions}

Next, I allow for interactions between institutions and the output gap. The literature suggests that good institutions should be associated with less procyclicality, that is we expect a positive coefficient on the interaction terms (good institutions raise the response of the balance to the gap). Moreover, weak institutions may be expected to raise procyclicality in bad times in particular: if a country is shut off from international capital markets during a crisis, it may be forced to tighten the budget in unfavorable conditions. In summary, the indices of institutional quality are likely candidates for complex nonlinear relationships.

In the linear model, the inclusion of the institutional variables and their interactions with the output gap fully accounts for procyclicality, as the output gap itself becomes insignificant, possibly due to a problem of collinearity. A number of institutional variables in levels are now significant and with the expected positive sign (Government Stability, the index of Socioeconomic Conditions, Religious Tensions, Risk Perceptions on GDP growth and on Foreign Debt). However, the interaction terms enter with conflicting signs. On the one hand, as suggested by the Alesina-Tabellini model (2005), less Corruption (higher index) leads to less procyclicality, as this variable raises the response of the primary balance to the gap. However, a few other interaction terms between the past gap and institutional variables (Internal Conflict, Ethnic Tensions) enter significantly with a "unexpected” negative coefficient, suggesting, counter-intuitively, that policy is more procyclical (response of the balance to the gap is lower) when institutions are stronger. The interaction between the index for Risk Perceptions on Debt and the output gap also enters with counter-intuitive negative sign, suggesting that policy is more procyclical when solvency perceptions are better. A possible explanation is that the institutional interaction variables are now picking up the "flat" segment of the response of the balance to the large recessions: if countries with weaker institutions experience "worse shocks" than countries with stronger institutions, weaker institutions may appear to be associated with less, rather than more, procyclicality (see also footnote 14 for an alternative explanation).

Again, the fiscal rule variables become insignificant when institutional variables are included. 
Table 6A. Linear Model with Fixed Effects, Fiscal Rules, and Institutions No Interactions

\begin{tabular}{lcccc}
\hline Parameter & Estimate & S.E. & T-ratio & P-value \\
\hline Primary balance & 0.54 & 0.04 & 14.36 & 0.00 \\
Debt-GDP ratio & 0.03 & 0.01 & 3.89 & 0.00 \\
Output gap & -0.07 & 0.04 & -1.70 & 0.09 \\
Fiscal rule & 0.33 & 0.37 & 0.90 & 0.37 \\
Gap-rule & 0.09 & 0.08 & 1.15 & 0.25 \\
Bureaucracy quality & -0.07 & 0.26 & -0.27 & 0.79 \\
Internal conflict & 0.12 & 0.13 & 0.90 & 0.37 \\
Government stability & 0.23 & 0.12 & 1.92 & 0.06 \\
Financial risk rating & -0.03 & 0.06 & -0.56 & 0.58 \\
External conflict & 0.12 & 0.12 & 0.99 & 0.32 \\
Ethnic tensions & 0.04 & 0.19 & 0.20 & 0.84 \\
Democratic accountability & 0.22 & 0.17 & 1.26 & 0.21 \\
Corruption & 0.18 & 0.17 & 1.04 & 0.30 \\
Composite risk rating & -0.05 & 0.07 & -0.68 & 0.50 \\
Socioeconomic conditions & 0.18 & 0.12 & 1.54 & 0.12 \\
Religious tensions & 0.64 & 0.20 & 3.18 & 0.02 \\
Political risk rating & -0.08 & 0.08 & -1.14 & 0.256 \\
Military in politics & 0.12 & 0.18 & 0.68 & 0.50 \\
Law and order & -0.01 & 0.19 & -0.08 & 0.94 \\
Risk perc_gdp & 0.22 & 0.09 & 2.45 & 0.01 \\
Risk perc_fordebt & 0.12 & 0.11 & 1.05 & 0.30 \\
Risk perc_exchstab & -0.03 & 0.09 & -0.40 & 0.69 \\
Risk perc_debt service & -0.01 & 0.11 & -0.12 & 0.90 \\
Constant & -0.95 & 2.77 & -0.34 & 0.73 \\
\hline
\end{tabular}

N. of Obs: 611;R-squared =0.59; Adj R-squared $=0.54 ;$ MSE $=2.18$.

Source: Author's calculations. 
Table 6B. MARS Model with Fixed Effects, Fiscal Rules, and Institutions, No Interactions

\begin{tabular}{lcccc}
\hline Parameter & Estimate & S.E. & T-ratio & P-value \\
\hline Constant & -4.39 & 0.34 & -12.85 & 0.00 \\
(0, debt-to-GDP ratio - 7.95) & 0.02 & 0.01 & 4.26 & 0.00 \\
(0, debt-to-GDP ratio - 89.14) & -0.38 & 0.13 & -3.02 & 0.00 \\
(0, debt-to-GDP ratio - 93.90) & 0.73 & 0.20 & 3.55 & 0.00 \\
(0, debt-to-GDP ratio - 124.43) & 0.27 & 0.08 & 3.48 & 0.00 \\
(0, debt-to-GDP ratio - 102.70) & -0.47 & 0.12 & -3.92 & 0.00 \\
(0, debt-to-GDP ratio - 144.41) & -0.20 & 0.07 & -2.97 & 0.00 \\
$(0$, output gap + 2.03) & -0.10 & 0.04 & -2.43 & 0.01 \\
& & & & \\
(0, primary balance + 4.82) & 0.79 & 0.04 & 20.59 & 0.00 \\
(0, primary balance - 4.27) & -1.03 & 0.25 & -4.07 & 0.00 \\
(0, primary balance - 6.28) & 0.87 & 0.34 & 2.54 & 0.01 \\
$(0$, bureaucracy quality - 2.00) & -0.35 & 0.11 & -3.07 & 0.00 \\
$(0$, religious tensions - 5.00) & & & & \\
\end{tabular}

N. of Obs: 640; R-Squared: 0.63; Adj R-squared: 0.62; MSE: 2.09

Source: Author's calculations. 
Figure 5. MARS Model with Fixed Effects, Fiscal Rules, Institutions: No Interactions
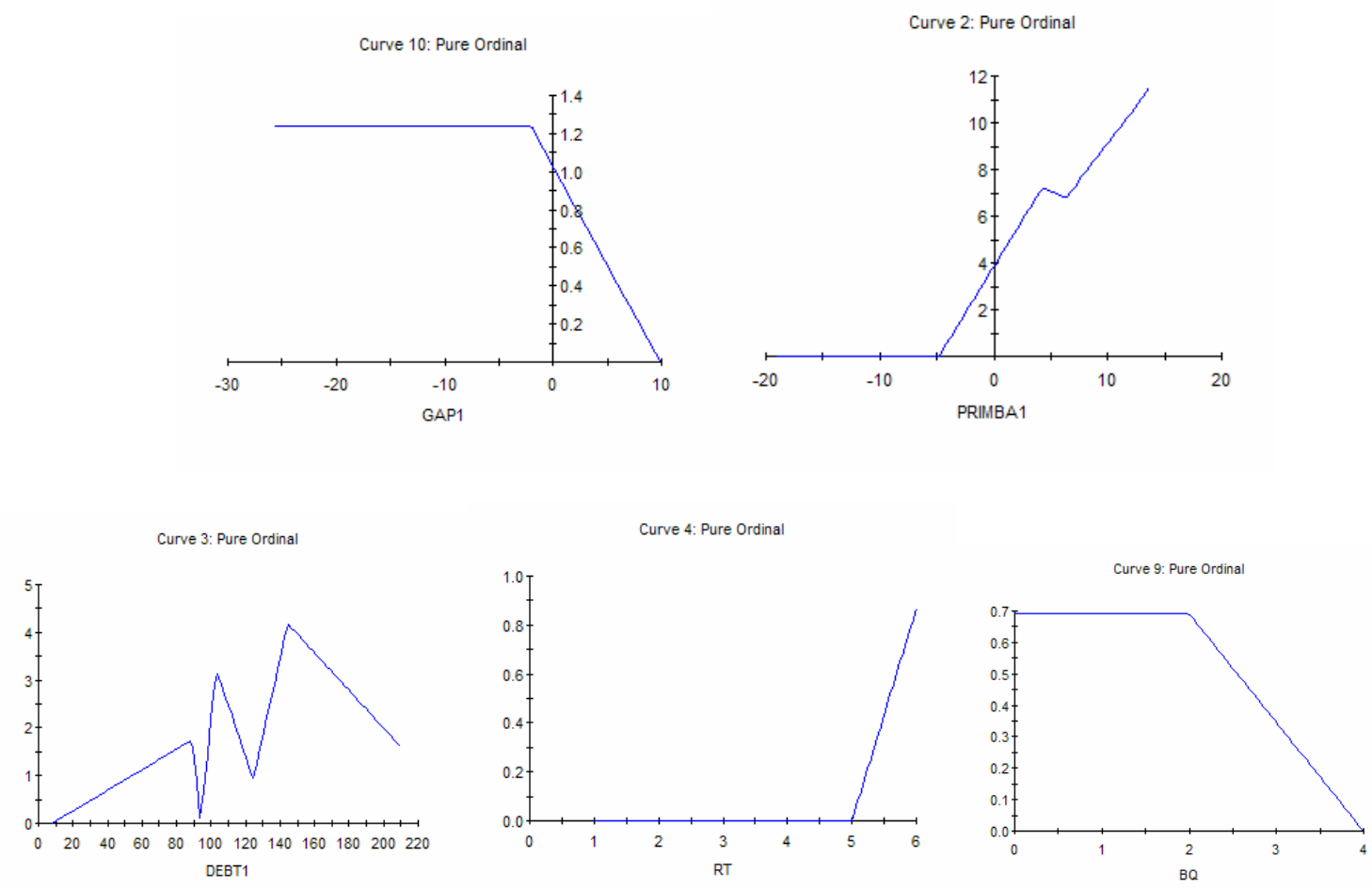

The MARS specification confirms many of these results. In particular, the interactions between the output gap and institutional variables largely account for the relationship between policy and the gap. Again, possibly reflecting collinearity, the past output gap only enters the final specification when interacted with the indexes of Bureaucratic Quality (BQ), the Risk Perceptions on Exchange Rate Stability (RP_EXCHS), on GDP Growth (RP_GDP), Internal (IC) and External Conflict (EC), and Military in Power (MIP). As Figure 6 shows, the debt-to-GDP ratio (DEBT1) enters significantly only above the threshold of 8 percent, while the lagged level of the balance (PRIMBA1) shows positive persistence only above -4.8 percent, and flattens out somehow above +4.2 percent.

The Exchange Rate Stability risk perception variable suggests that less vulnerability (a higher index) is on average associated with a deficit bias that is 0.6 percent of GDP lower, but only when vulnerability is already very low (the index is between 8 and the maximum 10). Table 7B and Figure 6 show the effect of interacting this variable with the lagged output gap. The balance reacts quite differently to the gap for "safe" (above 5 index) versus "risky" (below 5) values of the index. In the former, when little exchange risk is perceived, the primary balance falls slightly when the economic outlook improves, as tax windfalls are dissipated. By contrast, when exchange risk is perceived high, there balance rises as the economy improves. 
Somehow counter-intuitively, the Risk Perception on GDP Growth interaction variable has the expected positive sign (less vulnerability raises counter-cyclicality) only when the economy is enduring relatively "large recessions" (output gap between -2.2 percent and 8 percent), while the opposite holds in normal times.

Improvements in the index of Religious Tension (above the threshold 2 until the maximum 6) are associated with considerable increases in the level of the primary balance, as expected. The interpretation of the effect of the gap-interaction terms, however, is quite complex, as it depends on the level of the index and the gap. For intermediate values of the RT index, the primary balance first rises and then falls as the gap increases; for intermediate levels of the gap, an increase in the quality index is associated with higher balances (see Figure 6).

An improvement in the Internal Conflict index (which ranges from a minimum value of 3 to a maximum of 12, as conflict decreases) makes policy more countercyclical, and the effect appears to be stronger in very good times (gap above 6 percent).

Somewhat similarly, a higher index Bureaucracy Quality appears to raise countercyclicality but only when the economic outlook is favorable (gap between 3.5 and 6.2); the effect becomes less pronounced when the quality is already rather high (i.e., the index is between 3 and the maximum 4).

The effects of External Conflict on fiscal policy is significant only when the quality index is not too high (below 11, out of 12 notches); when the gap is positive and relatively high (above $13 / 4$ percent) better institutions appear to reduce procyclicality, while below $1 \frac{3}{4}$ the relationships appears driven by outliers (spikes).

Finally, an improvement in the rule of law and civil rights, as proxied by a higher Military in Power index, is associated with a more countercyclical policy only during "good times" (when the output gap exceeds -1.8), with a downward spike at 4 percent. During large recessions, however, the effect is reversed.

Overall, the evidence is consistent with the notion that better institutions on average are associated with a lower deficit bias; however, the effect on the degree of pro/countercyclicality is more difficult to discern: for many, but not all indicators, better institutions are associated with lower procyclicality only in good times, when, as we saw, the problem is more acute. However, the reverse seems to occur in bad times. Also, the effects of institutional quality seem to be subject to decreasing returns: the effects are stronger when institutions are very weak, but level off when institutions are sufficiently effective. Fiscal rules become insignificant when the institutional variables appear in the regressions, which suggest that fiscal frameworks may not exert an independent effect on fiscal policy when “deeper” institutional variables are controlled for. 
Table 7A.Linear Model with Fixed Effects, Fiscal Rules, and Institutions with Interactions

\begin{tabular}{|c|c|c|c|c|}
\hline Parameter & Estimate & S.E. & T-ratio & P-value \\
\hline Primary balance & 0.52 & 0.39 & 13.37 & 0.00 \\
\hline Debt-GDP ratio & 0.02 & 0.01 & 3.39 & 0.00 \\
\hline Output gap & -0.06 & 0.41 & -0.16 & 0.87 \\
\hline Fiscal rule & 0.39 & 0.39 & 1.00 & 0.32 \\
\hline Output Gap- Fiscal rule & -0.01 & 0.09 & -0.10 & 0.92 \\
\hline Bureaucracy quality & -0.10 & 0.265 & -0.38 & 0.70 \\
\hline Internal conflict & 0.20 & 0.14 & 1.47 & 0.14 \\
\hline Government stability & 0.25 & 0.12 & 2.08 & 0.04 \\
\hline Financial risk rating & -0.04 & 0.07 & -0.53 & 0.59 \\
\hline External conflict & 0.11 & 0.12 & 0.84 & 0.40 \\
\hline Ethnic tensions & -0.04 & 0.19 & -0.22 & 0.83 \\
\hline Democratic accountability & 0.24 & 0.18 & 1.35 & 0.18 \\
\hline Corruption & 0.22 & 0.18 & 1.22 & 0.22 \\
\hline Composite risk rating & -0.07 & 0.08 & -0.87 & 0.39 \\
\hline Socioeconomic conditions & 0.23 & 0.12 & 1.89 & 0.06 \\
\hline Religious tensions & 0.60 & 0.20 & 2.93 & 0.00 \\
\hline Political risk rating & -0.09 & 0.08 & -1.14 & 0.25 \\
\hline Military in politics & 0.18 & 0.18 & 0.97 & 0.33 \\
\hline Law and order & 0.11 & 0.20 & 0.59 & 0.56 \\
\hline Risk perc_gdp & 0.25 & 0.09 & 2.65 & 0.01 \\
\hline Risk perc foreign debt & 0.20 & 0.12 & 1.59 & 0.11 \\
\hline Risk perc_exch stab & -0.89 & 0.09 & -0.94 & 0.35 \\
\hline Risk perc_debt service & -0.07 & 0.11 & -0.64 & 0.52 \\
\hline Output gap_bureaucracy quality & -0.10 & 0.07 & -1.35 & 0.18 \\
\hline Output gap_internal conflict & -0.06 & 0.03 & -1.70 & 0.10 \\
\hline Output gap_government stability & -0.01 & 0.04 & -0.20 & 0.84 \\
\hline Output gap_financial risk rating & 0.00 & 0.02 & 0.02 & 0.98 \\
\hline Output gap_ethnic conflict & 0.00 & 0.03 & 0.09 & 0.93 \\
\hline Output gap_ethnic tension & -0.09 & 0.42 & -2.16 & 0.03 \\
\hline Output gap_democratic accountability & -0.01 & 0.04 & -0.34 & 0.73 \\
\hline Output gap_corruption & 0.09 & 0.05 & 1.74 & 0.08 \\
\hline Output gap_composite risk rating & 0.01 & 0.02 & 0.54 & 0.59 \\
\hline Output gap_socioeconomic conditions & -0.05 & 0.04 & -1.19 & 0.24 \\
\hline Output gap_religious tensions & -0.01 & 0.04 & -0.13 & 0.89 \\
\hline Output gap_political risk rating & 0.01 & 0.02 & 0.61 & 0.54 \\
\hline Output gap_military in politics & 0.02 & 0.05 & 0.38 & 0.71 \\
\hline Output gap_law \& order & 0.01 & 0.05 & 0.19 & 0.85 \\
\hline Output gap_Risk perc gdp & 0.00 & 0.02 & 0.01 & 0.99 \\
\hline Output gap_ Risk perc foreign debt & 0.03 & 0.03 & 0.90 & 0.37 \\
\hline Output gap_Risk perc exch stab & -0.02 & 0.02 & -0.83 & 0.40 \\
\hline Output gap_Risk perc debt service & -0.07 & 0.02 & -2.96 & 0.00 \\
\hline Constant & -0.26 & 2.91 & -0.09 & 0.93 \\
\hline
\end{tabular}

N. of Obs: 611; R-Squared: 0.61; Adj R-Squared: 0.55; MSE: 2.16.

Source: Author's calculations. 
Table 7B. MARS Model with Fixed Effects, Fiscal Rules, Institutions, and Interactions

\begin{tabular}{|c|c|c|c|c|}
\hline Parameter & Estimate & S.E. & T-ratio & P-value \\
\hline Constant & -5.38 & 0.78 & -6.85 & 0.00 \\
\hline$(0$, primary balance +4.83$)$ & 0.75 & 0.03 & 21.56 & 0.00 \\
\hline$(0$, primary balance -4.27$)$ & -.41 & 0.10 & -4.21 & 0.00 \\
\hline (0, debt-to-GDP ratio - 7.95) & 0.02 & 0.00 & 5.39 & 0.00 \\
\hline (0, 8.00 - Risk perc_exch rate stab) & -.59 & 0.18 & -3.34 & 0.00 \\
\hline $\begin{array}{l}(0, \text { Risk Perc_exch rate stab }-5.00) *(0, \text { output gap }+ \\
25.60)\end{array}$ & -0.01 & 0.00 & -3.30 & 0.00 \\
\hline$(0,5.00-$ Rperc_ex rate stab $) *(0$, output gap +25.60$)$ & 0.05 & 0.01 & 4.91 & 0.00 \\
\hline$(0$, output gap +8.45$) *(0$, Risk perc_GDP +0.90$)$ & 0.04 & 0.01 & 3.90 & 0.00 \\
\hline$(0$, output gap +2.21$) *(0$, Risk perc_GDP +0.90$)$ & -0.11 & 0.03 & -4.16 & 0.00 \\
\hline$(0$, religious tension -2.00$)$ & 1.30 & 0.24 & 5.38 & 0.00 \\
\hline$(0$, output gap +25.60$) *(0,2.00$ - religious tension $)$ & -0.09 & 0.04 & -2.42 & 0.02 \\
\hline$(0$, output gap +25.60$) *(0,3.00$ - religious tension $)$ & 0.07 & 0.02 & 3.35 & 0.00 \\
\hline$(0$, output gap +9.9$) *(0$, religious tension -3.00$)$ & -0.11 & 0.03 & -4.06 & 0.00 \\
\hline$(0$, output gap +0.71$) *(0$, religious tension -3.00$)$ & 0.28 & 0.07 & 3.94 & 0.00 \\
\hline$(0$, output gap -4.60$) *(0$, religious tension -2.00$)$ & -1.31 & 0.46 & -2.88 & 0.00 \\
\hline$(0$, output gap -6.23$) *(0$, religious tension -2.00$)$ & 3.73 & 1.38 & 2.71 & 0.01 \\
\hline$(0$, output gap -0.42$) *(0$, internal conflict -3.00$)$ & -0.10 & 0.02 & -4.26 & 0.00 \\
\hline$(0$, output gap -6.10$) *(0$, internal conflict -3.00$)$ & 1.25 & 0.38 & 3.25 & 0.00 \\
\hline$(0$, output gap -1.13$) *(0,11.00$ - external conflict $)$ & -14.89 & 2.58 & -5.76 & 0.00 \\
\hline$(0$, output gap -1.25$) *(0,11.00$ - external conflict $)$ & 23.01 & 4.44 & 5.18 & 0.00 \\
\hline$(0$, output gap -1.52$) *(0,11.00$ - external conflict $)$ & -28.81 & 8.21 & -3.51 & 0.00 \\
\hline$(0$, output gap -1.61$) *(0,11.00$ - external conflict $)$ & 33.65 & 10.37 & 3.24 & 0.00 \\
\hline$(0$, output gap -1.75$) *(0,11.00$ - external conflict $)$ & -12.87 & 3.96 & -3.25 & 0.00 \\
\hline$(0$, bureaucracy quality -3.00$) *(0$, output gap -0.21$)$ & -0.68 & 0.18 & -3.76 & 0.00 \\
\hline$(0$, output gap -3.49$) *(0$, bureaucracy quality -0.00$)$ & 1.83 & 0.34 & 5.35 & 0.00 \\
\hline$(0$, output gap -6.23$) *(0$, bureaucracy quality -0.00$)$ & -8.63 & 1.94 & -4.44 & 0.00 \\
\hline$(0$, output gap +25.60$) *(0$, military in politics -0.00$)$ & -0.01 & 0.00 & -3.45 & 0.00 \\
\hline$(0$, output gap +1.86$) *(0$, military in politics -0.00$)$ & 0.16 & 0.03 & 4.64 & 0.00 \\
\hline$(0$, output gap -3.97$) *(0$, military in politics -0.00$)$ & -2.66 & 0.46 & -5.77 & 0.00 \\
\hline$(0$, output gap -4.58$) *(0$, militiary in politics -0.00$)$ & 2.94 & 0.56 & 5.24 & 0.00 \\
\hline
\end{tabular}

N. of Obs: 640; R-Squared: 0.68; Adj R-Squared: 0.67; MSE: 1.96

Source: Author's calculations. 
Figure 6. MARS Model with Fixed Effects, Fiscal Rules, Institutions, and Interactions
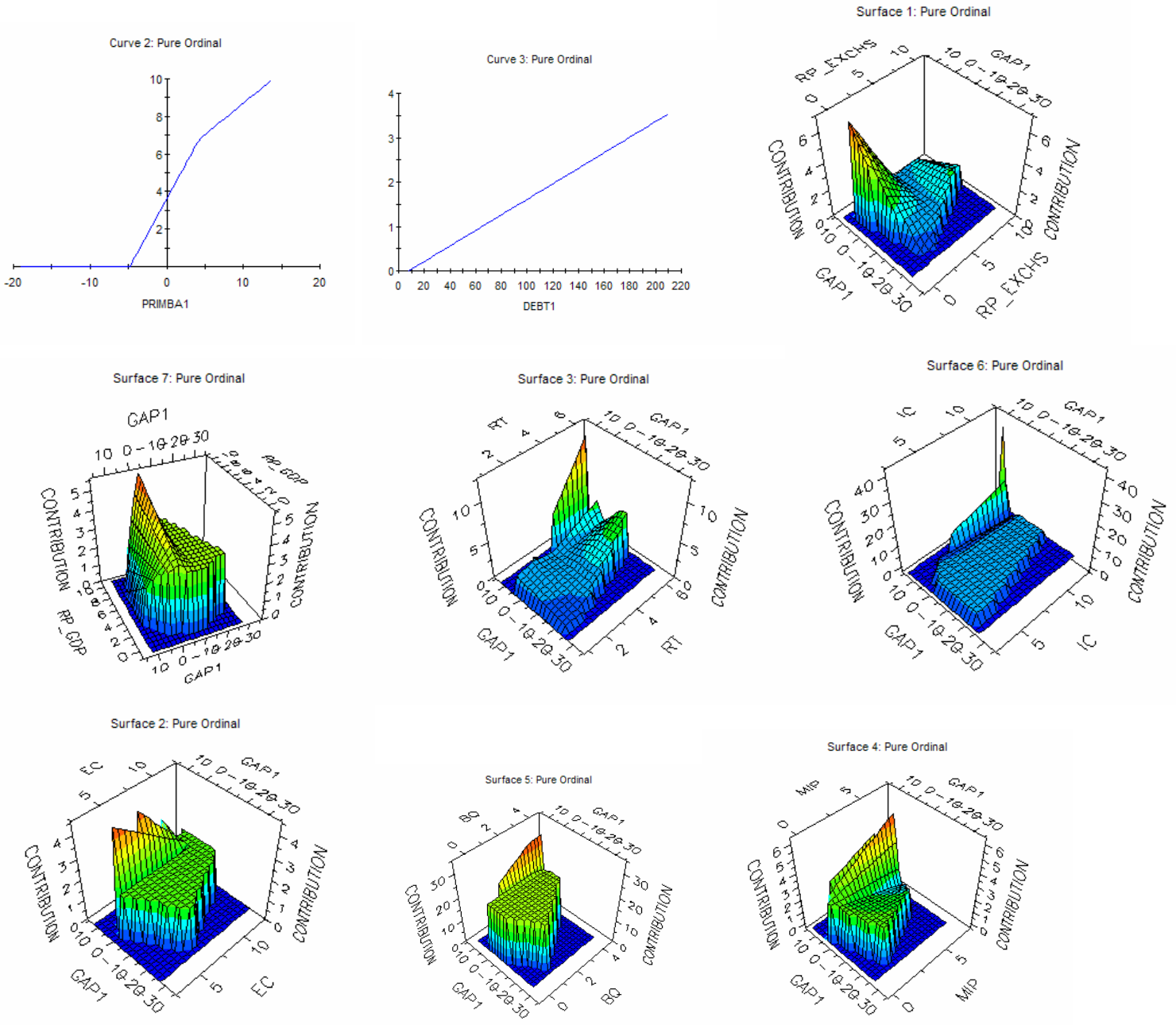

\section{B. Shocks and Heterogeneity}

This section focuses on the question whether fiscal policy in developing and developed countries responds "differently" to the business cycle.

Our previous result suggests that the answer to this question cannot be obtained, as done in the literature, by simply dividing the sample into two groups and contrasting the responses of the fiscal balance to the output gap, assuming linearity. Suppose the "true" model is that of Figure 1: then developing countries will show a flatter or steeper reaction function depending on the sample distribution of shocks in the two samples: for example, if (moderately) bad shocks are relatively more frequent in developing countries, the linear model will produce a 
flatter reaction function. This is exactly what happens when the linear model (with only fixed effects, to maximize the degrees of freedom) is fitted to developed ${ }^{15}$ and developing countries separately, see Table 8: the output gap enters negatively, but is not significant in the developing countries, while it is negative and significant for developed economies.

Table 8A. Linear Model, Developing Countries, Fixed Effects

\begin{tabular}{lcccc}
\hline Parameter & Estimate & S.E. & T-ratio & P-value \\
\hline Primary balance & 0.47 & 0.04 & 11.54 & 0.00 \\
Public debt & 0.02 & 0.01 & 4.30 & 0.00 \\
Output gap & -0.04 & 0.03 & -1.34 & 0.18 \\
Constant & -2.77 & 1.02 & -2.71 & 0.01 \\
\hline
\end{tabular}

N. of Obs: 470; R-Squared: 0.59; Adj R-Squared: 0.55; MSE: 2.29.

Source: Author's calculations.

Table 8B. Linear Model, Developed Countries, Fixed Effects

\begin{tabular}{lcccc}
\hline Parameter & Estimate & S.E. & T-ratio & P-value \\
\hline Primary balance & 0.84 & 0.04 & 21.82 & 0.00 \\
Public debt & 0.02 & 0.00 & 3.11 & 0.00 \\
Output gap & -0.14 & 0.07 & -2.03 & 0.04 \\
Constant & -1.21 & 0.65 & -1.85 & 0.06 \\
\hline
\end{tabular}

N. of Obs: 267; R-squared: 0.76; Adj R-Squared: 0.74; MSE: 1.66.

Source: Author's calculations.

The distribution of the output gaps for developed and developing countries is shown below (see Figure 7). In the former group, it has zero mean and ranges from $-4 \frac{1}{2}$ percent to $41 / 2$ percent. In developing countries the mean is negative and the support ranges from 24 percent to 15 percent. The standard deviation of output gaps in developing countries is more than double that in developed economies (3.6 against 1.6). While the distribution of gaps is "close" to Normal for developed countries, it appears significantly skewed to the left (i.e., bad shocks are particularly frequent) for developing ones. ${ }^{16}$

${ }^{15}$ In the sample, see Table 1, developed countries are defined as Australia, Austria, Canada, Denmark, France, Italy, Japan, Netherlands, Norway, Spain, Sweden, and United Kingdom.

${ }^{16}$ The hypothesis of normality of the gap distribution cannot be rejected for developed countries by the test of D'Agostino and others, 1990, at a confidence level of 11 percent: the Skewness $=0.25$ (it is 0 in a Normal distribution) and the Kurtosis $=2.95$ (it is 3 in a Normal distribution). Conversely, normality of the gap distribution for developing countries can be rejected with $p=0.0000$, the Skewness $=-0.73$ (a negative sign indicating more observations in the left tail) and Kurtosis = 7.6. 
Figure 7. Histogram of Output Gap
A. Developed countries
B. Developing countries
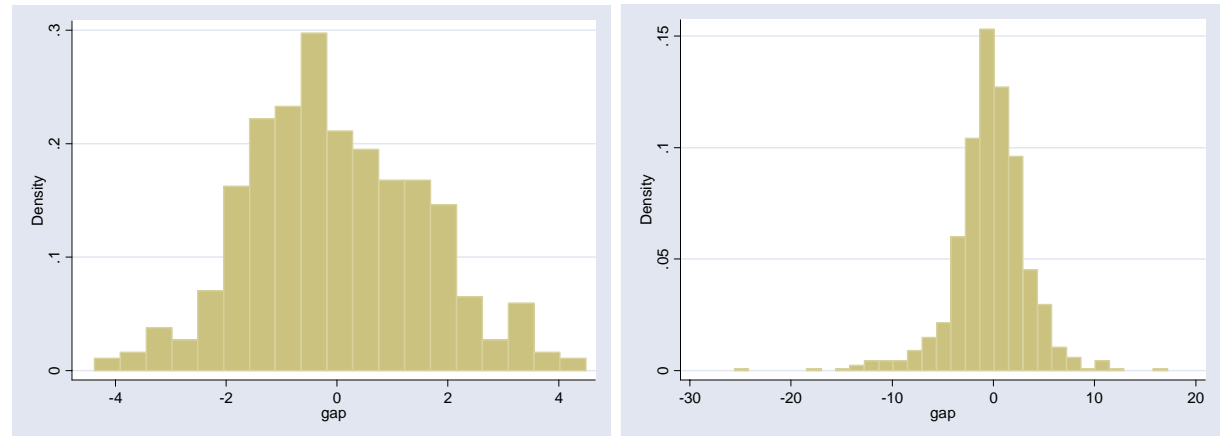

By contrast, if we run two separate MARS models for the two subsamples, the results are not that dissimilar. Figure 8 shows relationships between the primary balance-GDP ratio and the output gap in the two samples (the estimates are shown in Table 9): both have flat segments for "bad states," which in developed countries are identified as gaps below $1 / 2$ percent, and in developing economies below -5 percent. Both have negative coefficients (i.e., procyclical policy) in "good states."

The main differences are as follows: first, "bad times" in developing countries (output gaps below -5 percent) are much worse than "bad times" in industrialized countries (below $1 / 2$ percent), so that one frequently observes procyclical behavior in developing countries also during large recessions. Second, once in "good times," fiscal policy is actually more procyclical in developed economies, where the coefficient on the output gap is almost three times that of developing countries (its point estimate, obtained summing up the coefficients of output gaps, $16.745-36.097+19.108$, equals to -0.244 , against -0.087 in developing countries).

Clearly, the studies that assume linearity and consider different samples (gap distributions) are bound to find potentially conflicting results, depending on the countries and time periods analized.

A more formal strategy for answering the question above is to test for "poolability" of the two samples. The test developed by Toro-Vizcarrondo and Wallace (1969), considers the trade-off between "bias” introduced by pooling and the “efficiency” gains obtained. Consistently with the previous results, the assumption of poolability is rejected for both the linear and the non linear model at standard confidence levels. 
Table 9A. MARS Model, Developing Countries, Fixed Effects

\begin{tabular}{lcccc}
\hline Parameter & Estimate & S.E. & T-ratio & P-value \\
\hline Constant & -2.415 & 0.328 & -7.372 & 0.00 \\
\hline & & & & \\
\hline (0,.primary balance +4.23) & 0.649 & 0.055 & 11.743 & 0.00 \\
(0,. primary balance - 3.930 ) & 5.177 & 1.988 & 2.604 & 0.010 \\
(0,-4.230- primary balance) & -0.324 & 0.142 & -2.279 & 0.023 \\
(0,.primary balance - 4.470) & -12.858 & 4.443 & -2.894 & 0.004 \\
(0,. primary balance - 4.92) & 7.587 & 2.635 & 2.879 & 0.004 \\
& & & & \\
(0,. debt-to-GDP ratio -91.36) & -1.426 & 0.449 & -3.175 & 0.002 \\
(0,. debt-to-GDP ratio - 93.000) & 1.900 & 0.527 & 3.602 & 0.00 \\
(0,. debt-to-GDP ratio -102.7) & -0.794 & 0.144 & -5.521 & 0.00 \\
(0,. debt-to-GDP ratio - 122.780) & 0.686 & 0.133 & 5.157 & 0.00 \\
(0,. debt-to-GDP ratio -137.47) & -0.392 & 0.095 & -4.144 & 0.00 \\
& & & & \\
(0,.output gap + 4.89) & -0.087 & 0.039 & -2.242 & 0.025 \\
\hline
\end{tabular}

N. of Obs: 470 ; R-Squared: 0.597; Adj R-Squared: 0.583; MSE: 2.215.

Source: Author's calculations.

Table 9B. MARS Model, Developed Countries, Fixed Effects

\begin{tabular}{lcccc}
\hline Parameter & Estimate & S.E. & T-ratio & P-value \\
\hline (0,.primary balance +4.8) & 0.995 & 0.042 & 3.364 & 0.00 \\
(0,.primary balance -4.83) & -3.48 & 1.030 & -3.379 & 0.00 \\
$(0,$. primary balance - 5.320) & 3.155 & 1.103 & 2.860 & 0.005 \\
& & & & \\
$(0,$. output gap - 0.248) & 16.745 & 6.137 & 2.728 & 0.007 \\
$(0,$. output gap - 0.364) & -36.097 & 12.768 & -2.827 & 0.005 \\
$(0,$. output gap - 0.474) & 19.108 & 6.954 & 2.748 & 0.006 \\
& & & & 0.010 \\
$(0,$. debt-to-GDP ratio- 39.841) & 0.011 & 0.004 & 2.607 & 0.00 \\
& & & & \\
Constant & -4.836 & 0.41 & -20.682 & \\
\hline
\end{tabular}

N. of Obs: 267; R-Squared: 0.779 ; Adj R-Squared: 0.772 ; MSE: 1.570.

Source: Author's calculations. 
Figure 8. MARS Models
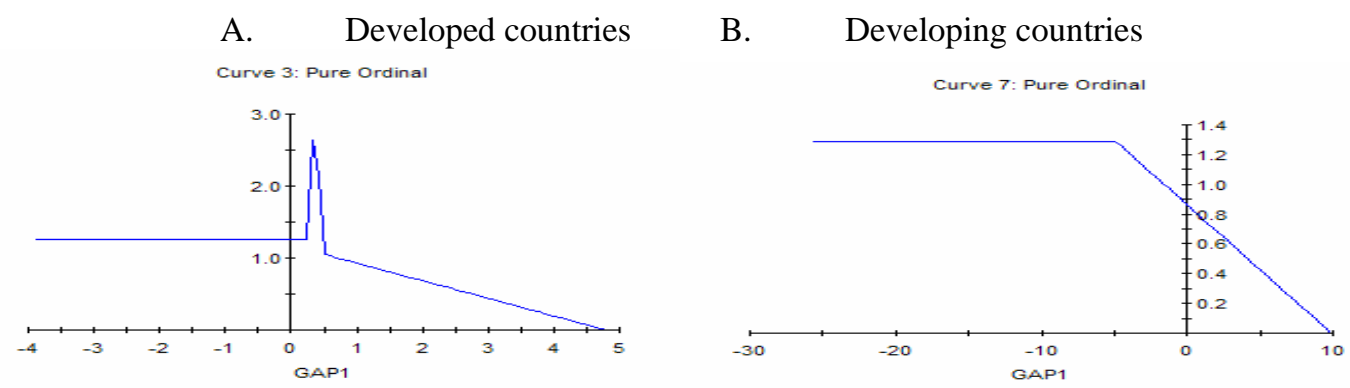

\section{CONCLUSIONS}

Four are the main findings of this paper. The first concerns the role of shocks. The policy reaction to the business cycle is different depending on the state of the economy: fiscal policy is "acyclical" during bad times, while it is largely procyclical during good times. Since the slope of the policy reaction function with respect to the output gap changes with the state of the economy, this finding implies that it is not generally correct to isolate a single parameter describing how pro- or countercyclical fiscal policy is.

The second result concerns the role of fiscal rules, such as limits on the deficit, borrowing or spending. The evidence suggests that these constraints may reduce the deficit on average. Moreover, fiscal rules seem to enhance, rather than weaken, countercyclical policy. This implies that appropriate fiscal frameworks may improve the long term sustainability of fiscal policy without compromising its short term stabilization effectiveness. However, the evidence also suggests that appropriate fiscal frameworks may not exert an independent effect on fiscal policy when controling for "deeper” institutional variables.

Third, strong “institutions” are found to reduce the deficit bias on average. However, the effect on procyclicality is ambiguous: for many, but not all indicators, better institutions are associated with lower procyclicality in good times, when the problem is more acute; however, the reverse often occurs in bad times. The effects of institutional quality also appear subject to decreasing returns. The effect is typically strong when institutions are very weak, but levels off when institutions are sufficiently strong.

Fourth, these conclusions have important implications for assessing "how different" is the response of fiscal policy to shocks in developing and developed countries. The evidence supports the conjecture that observed differences between developing and developed countries at least partially reflect different shocks, rather than different behavior. For both groups of countries, policy is largely acyclical in bad times and procyclical in good times: The main difference is that "bad times" in developing countries are much worse than "bad times" in industrialized countries, so that one frequently observes procyclical behavior in developing countries also during large recessions. However, once in "good times," fiscal policy is more procyclical in developed economies. 


\section{References}

Alesina, Alberto, and Guido Tabellini, 2005, "Why is Fiscal Policy often Procyclical?” (Unpublished; Milan: IGIER-Bocconi University)

Balassone, Fabrizio, and Maura Francese, 2004, “Cyclical Asymmetry in Fiscal Policy, Debt Accumulation and the Treaty of Maastricht,” Temi di Discussione, No. 531, December (Rome: Banca d'Italia).

Bohn, Henning, 1998, “The Behavior of U.S. Public Debt and Deficits,” Quarterly Journal of Economics, Vol. 113 (August), pp. 949-63.

Bouthevillain, Carine, Philippine Cour-Thimann, Gerrit van den Dool, Pablo Hernández de Cos, Geert Langenus, Matthia Mohr, Sandro Momigliano, and Mika Tujula, 2001, “Cyclically-Adjusted Budget Balances: An Alternative Approach,” ECB Working Paper No. 77 (Frankfurt: European Central Bank).

Breiman, L., J.H. Friedman, R. Olshen, and C.J. Stone, 1984, "Classification and Regression trees,” (New York: Chapman \& Hall).

Buiter, Willem, Giancarlo Corsetti and Nouriel Roubini, 2003, "Excessive Deficits: Sense and Nonsense in the Treaty of Maastricht," Economic Policy, Vol. 16, pp. 58-60.

Buti, Marco, Carlos Martinez-Mongay, Khalid Sekkat, and Paul van den Noord, 2002, "Macroeconomic Policy and Structural Reform: a Conflict Between Stabilization and Flexibility," Monetary and Fiscal Policies in EMU: Interactions and Coordination, ed. By Marco Buti (Cambridge: Cambridge University Press).

Buti, Marco, and A. Sapir, 1998, “Economic Policy in EMU: A Study by the European Commission Service,” (Oxford: Clarendon Press).

Celasun, Oya, Xavier Debrun, and Jonathan D. Ostry, 2005, “Primary Surplus Behavior and Risks to Public Debt Sustainability in Emerging Market Countries: A 'Fan-Chart' Approach,” (unpublished; Washington: international Monetary Fund).

Casella, Alessandra, 1999, “Tradable Deficit Permits: Efficient Implementation of the Stability Pact in the European Monetary Union,” Economic Policy, Vol. 29, (October), pp. 323-61.

D’Agostino, R.B., A. Balanger and R.B. D’Agostino Jr., 1990, “A Suggestion for Using Powerful and Informative Test of Normality,” The American Statistician, No. 4, pp. 316-21. 
De Veaux, R.D. and L.H. Ungar, 1994, "Multicollinearity: A tale of Two Nonparametric Regressions,” in: P. Cheeseman, P. \& Oldford, R.W. (eds.) Selecting models from data: AI and Statistics IV, pp. 293-302 (New York, NY: Springer-Verlag).

European Commission, 2001, “Public Finances in EMU-2001,” European Economy, Reports and Studies, No. 3.

Friedman, J.H., 1991, “Multivariate Adaptive Regression Splines (with discussion),” Annals of Statistics, No. 19, March, pp. 1-141.

Fatás, Antonio, and Ilian Mihov, 2001, “Government Size and Automatic Stabilizers: International and Intranational Evidence,” Journal of International Economics, Vol. 55, No. 1, pp. 3-28.

— 2003, “The Case for Restricting Fiscal Policy Discretion,” Quarterly Journal of Economics, Vol. 118, No. 4, pp. 1419-47, (Cambridge, Massachusetts: MIT Press).

Galí, Jordi, and Roberto Perotti, 2003, "Fiscal Policy and Monetary Integration in Europe," Economic Policy, Vol. 18, No. 37 (October), pp. 535-72.

Gavin, Michael, Ricardo Hausmann, Roberto Perotti, and Ernesto Talvi, 1996, "Managing Fiscal Policy in Latin America and the Caribbean: Volatility, Procyclicality, and Limited Creditworthiness,” IDB Working Paper No. 326 (Washington: InterAmerican Development Bank).

Gavin, M. and R. Perotti, 1997, "Fiscal Policy in Latin America,” NBER Macroeconomic Annual, (Cambridge, Massachusetts: National Bureau of Economic Research).

Guerson, Alejandro, 2003, “On the Optimality of Procyclical Fiscal Policy When Governments Are Not Credible,” (unpublished Ph.D. thesis; Washington: George Washington University).

Hallerberg, Mark, Rolf Strauch, and Jürgen von Hagen, 2001, “The Use and Effectiveness of Budgetary Rules and Norms in EU Member States,” Working Paper, (Amsterdam: Dutch Ministry of Finance).

_ Effectiveness,” Hacienda Publica Espanola, Monográfico, No.167, pp. 201-25.

Hercowitz, Zvi and Michel Strawczynski, 2004, "Cyclical Ratcheting in Government Spending: Evidence from the OECD,” The Review of Economics and Statistics, February, 86 (1), pp. 353-61.

International Country Risk Guide ICRG, 2005, http://www.icrgonline.com. 
International Monetary Fund, 2003, World Economic Outlook, September 2003: A Survey by the Staff of the International Monetary Fund, World Economic and Financial Surveys (Washington).

— 2005, World Economic Outlook, September 2005: A Survey by the Staff of the International Monetary Fund, World Economic and Financial Surveys (Washington). , 2005b, Fiscal Responsibility Laws (Unpublished: Washington, International Monetary Fund)

Kaminsky, Graciela L., Carmen Reinhart, and Carlos Vegh, 2004, "When it Rains, it Pours: Procyclical Capital Flows and Macroeconomic Policies,” NBER Working Paper No. 10780 (Cambridge, Massachusetts: National Bureau of Economic Research).

Kaufmann, D., A. Kray and M. Mastruzzi, 2005, “Governance Matters IV: Governance Indicators for 1996-2004,” World Bank Policy Research Working Paper 3630, June (Washington: World Bank).

Kopits, George, 2004, “Overview of Fiscal Policy Rules for Emerging Markets,” in G. Kopits (ed.), Rules Based Fiscal Policy in Emerging Markets: Background, Analysis and Prospects, (New York: Palgrave Macmillan).

- and Steven Symansky, 1998, Fiscal Policy Rules, IMF Occasional Paper No. 162 (Washington: International Monetary Fund).

Lane, A. and P. Tornell, 1999, “The Voracity Effect”, The American Economic Review, Vol.89, 1, pp. 22-46.

Manasse, Paolo, 2005, “Deficit Limits, Budget Rules, and Fiscal Policy,” IMF Working Paper 05/120 (Washington: International Monetary Fund).

Manasse, Paolo, and Nouriel Roubini, 2005, "Rules of Thumb for Sovereign Debt Crises," IMF Working Paper 05/42 (Washington: International Monetary Fund).

Mélitz, Jacques, 2004, "Non-Discretionary and Automatic Fiscal Policy in the EU and the OECD,” CEPR Working Paper No. 4988 (London: Centre for Economic Policy Research).

OECD/World Bank Budget Practices and Procedures Database, 2003 http://www.oecd.org/document/61/0,2340,en_2649_33735_2494461_1_1_1_1,00.ht $\underline{\mathrm{ml}}$

Perry, Guillermo, 2004, “Can fiscal rules Help Reduce Macroeconomic Volatility?” in RulesBased Fiscal Policy in Emerging Markets: background, analysis and prospects, Kopits ed., (New York: Palgrave Macmillan). 
Lane, Philip, and Aaron Tornell, 1999, “The Voracity Effect,” The American Economic Review, Vol. 89, No.1, pp. 22-46.

Schmitt-Grohe, Stephanie, and Martin Uribe, 2004, “Optimal Simple and Implementable Monetary and Fiscal Rules,” NBER Working Paper 10253 (Cambridge, Massachusetts: National Bureau of Economic Research).

Serven, Luis, 1998, “Macroeconomic Uncertainty and Private Investment in LDCs: an Empirical Investigation,” Working Paper No. 2035 (Washington: World Bank).

Talvi, Ernesto, and Carlos Vegh, 2005, “Tax Base Variability and Procyclicality of Fiscal Policy,” Journal of Development Economics, forthcoming.

Tanner, Evan, 2003, "Fiscal Rules and Countercyclical Policy: Frank Ramsey Meets GrammRudman-Hollings,” IMF Working Paper 03/220 (Washington: International Monetary Fund).

van den Noord, Paul, 2000, “The Size and Role of Automatic Fiscal Stabilizers in the 1990s and Beyond,” Economics Department Working Paper No. 230 (Paris: Organization for Economic Cooperation and Development).

World Bank, 2000, “Attacking Poverty,” World Development Report (Washington: World Bank).

von Hagen, Jürgen, Andrew Hughes-Hallett, and Rolf Strauch, 2000, “Budgetary Consolidation in EMU,” European Economy: Reports and Studies, No. 148 (Brussels: European Commission). 